\title{
Radiogenic heat production in granitoids from the Sierras de Córdoba, Argentina
}

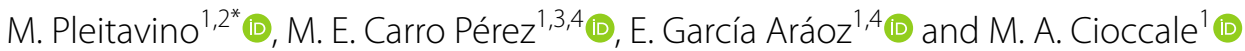

\section{*Correspondence:}

mpleitavino@unc.edu.ar

1 Facultad de Ciencias

Exactas, Físicas y Naturales,

Universidad Nacional de

Córdoba, Av. Vélez Sarsfield

1611, X5016CGA Córdoba,

Argentina

Full list of author information is available at the end of the article

\begin{abstract}
One of the most important processes of heat generation from the Earth's interior is the radioactive decay of isotopes. The main hosts of the major radiogenic elements $\mathrm{U}, \mathrm{Th}$ and $\mathrm{K}$ in the crust are granitoids. The Sierras de Córdoba are formed of dissimilar granitic intrusions emplaced by a series of magmatic events that occurred during the Paleozoic. The different granitoids are classified as A-type, I-type, and S-type, and there is also a magmatic expression corresponding to the Famatinian period which exhibits TTG-type characteristics. In this work, the geochemical concentrations of the radiogenic elements of the granitic intrusions making up the Sierras de Córdoba were compiled in a single database. The radiogenic heat production of the Sierras de Córdoba granitoids was evaluated, making this the first study of radiogenic heat generation in the area. The radiogenic heat production showed variability for the different events, with the highest values found in Achalian magmatism and early Carboniferous magmatism, which are represented by A-type granitoids. The Capilla del Monte pluton has the highest heat production rate, with a value of $4.54 \pm 1.38 \mu \mathrm{W} / \mathrm{m}^{3}$. The lowest values were found in the TTG-type granitoids and in the S-type granitoids, all of which belong to the Famatinian magmatic event. The range of values for this magmatic event goes from $0.26 \pm 0.05 \mu \mathrm{W} / \mathrm{m}^{3}$ for the San Agustin pluton to $1.19 \pm 0.50 \mu \mathrm{W} / \mathrm{m}^{3}$ for the La Playa pluton. An empirical ternary model is presented for the Sierras de Córdoba that involves the concentrations of the elements $\mathrm{U}$, Th and $\mathrm{K}$, and the radiogenic heat production, with a distinction for the petrogenetic types according to the S-I-A-M classification. The thermal manifestations located on the Capilla del Monte pluton could be related to the radioactive heat generation of the intrusion, involving both the neotectonic activity of the area and the radiogenic heat production. The results provide new opportunities for studying temperature variation within some of these intrusions and to evaluate the geothermal potential of the granitoids of Córdoba.
\end{abstract}

Keywords: HHP granitoids, Radiogenic heat production, Geotherm, Sierras de Córdoba

\section{Introduction}

The heat generated by the decay of radioactive elements present in rocks is a key factor in geothermal studies, particularly in the interpretation of continental heat flux density data (Abbady and Al-Ghamdi 2018). Determinations of heat flux density and radiogenic heat production rate provide information on the temperature and structure of

(c) The Author(s) 2021. This article is licensed under a Creative Commons Attribution 4.0 International License, which permits use, sharing adaptation, distribution and reproduction in any medium or format, as long as you give appropriate credit to the original author(s) and the source, provide a link to the Creative Commons licence, and indicate if changes were made. The images or other third party material in this article are included in the article's Creative Commons licence, unless indicated otherwise in a credit line to the material. If material is not included in the article's Creative Commons licence and your intended use is not permitted by statutory regulation or exceeds the permitted use, you will need to obtain permission directly from the copyright holder. To view a copy of this licence, visit http://creativeco mmons.org/licenses/by/4.0/ 
the continental crust (Rybach 1988). Several authors, including Artemieva and Mooney (2001), McLaren et al. (2006), Jaupart and Mareschal (2007), Hasterok and Chapman (2011), Mareschal and Jaupart (2013), Jaupart et al. (2016), Artemieva et al. (2017), Hasterok et al. (2018), Leat et al. (2018), and Zhou et al. (2020), have analyzed the magnitude and distribution of these parameters in different parts of the world and at different scales, and found notable dispersion.

As reported by Zhou et al. (2020), in continental intraplate regions, differences in the geothermal regime are mainly linked to the amount and distribution of radiogenic elements in crustal rocks. Granitoids have the greatest influence on surface heat flow and the geothermal regime of the upper crust (McLaren et al. 2006; Mareschal and Jaupart 2013; McLaren and Powell 2014; Jaupart and Mareschal 2015; Jaupart et al. 2016; Artemieva et al. 2017), since the radiogenic elements tend to concentrate towards the more evolved stages of a magma. Therefore, an increase in the heat production rate can be related to $\mathrm{SiO}_{2}$ content (Artemieva 2011), to a certain degree. Rybach (1976) estimates an average heat production rate for granites from uranium, thorium and potassium contents; the value obtained was $2.45 \mu \mathrm{W} / \mathrm{m}^{3}$. Artemieva et al. (2017) estimates an average value of approximately $2.00 \mu \mathrm{W} / \mathrm{m}^{3}$ based on 500 entries from a global database with samples from Archean to Cenozoic ages. The knowledge of the content and distribution of radiogenic elements in granitoids is essential for estimating their heat production capacity and for analyzing their potential as a geothermal resource.

Different authors have investigated the geothermal potential of rock bodies according to their content of radiogenic elements (among them McCay and Younger 2017 and Zhou et al. 2020). Gillespie et al. (2013) suggest that, in general, a heat production rate (A) $>4.00 \mu \mathrm{W} / \mathrm{m}^{3}$ is interesting for geothermal exploration in direct use applications, since this value tends to be high enough to significantly raise the geothermal gradient above that of the surrounding rock. Rollin (1984) and McCay and Younger (2017) postulate that even if the heat production in the body is relatively small (a few $\mu \mathrm{W} / \mathrm{m}^{3}$ for granite), large volumes of rock could mean that there is a sufficient amount of heatgenerating rock; this could raise the geothermal gradient above the background gradient derived from the mantle by the conduction phenomenon. Furthermore, the potential will eventually be defined by a conjunction of factors and constraints prevailing in the area. For example, rock bodies with slightly lower radiogenic heat production values, buried under an insulating sedimentary cover, allowing the sedimentary cover to accumulate the heat released from the rock body. Taking into account the existence of other influential factors, McCay and Younger (2017) redefine this threshold, suggesting that a high heat producer (HHP) granite is any granitoid with a heat production value greater than $5.00 \mu \mathrm{W} / \mathrm{m}^{3}$; granite plutons with heat production rates between 3.00 and $5.00 \mu \mathrm{W} /$ $\mathrm{m}^{3}$ are classified as granites with marginal heat production (MHP), which could eventually generate enough geothermal gradients for direct heat use instead of the higher temperatures required for electricity generation; and plutons with a rate below $3.00 \mu \mathrm{W} / \mathrm{m}^{3}$ are classified as low heat production (LHP) granites. Instead, Zhou et al. (2020), define a threshold for high-temperature geothermal deposits as equivalent to a heat reservoir of more than $1 \times 10^{5} \mathrm{~J} / \mathrm{y}$ in the South Block of China.

This work provides an overview of the heat production of the Sierras de Córdoba's granitoids using a compilation of existing data on the concentrations of the radiogenic 
elements $\mathrm{U}$, Th and $\mathrm{K}$. The rate of radiogenic heat production and the heat reservoir for the main granitic bodies are determined, and a statistical analysis of the data is carried out, from which certain trends are suggested. An empirical model is proposed for the Sierras de Córdoba using the proportional concentrations of the elements $\mathrm{U}$, Th and $\mathrm{K}$ and the radiogenic heat production for the different types of granitic rocks according to the S-I-A-M classification. Finally, it is proposed that some of the thermal manifestations known in the Sierras de Córdoba (Fig. 1) are linked to a granite pluton of high heat production value; therefore, the thermal manifestations could be related to a co-participation of radiogenic heat production and the area's Neogene tectonic activity.

\section{Background}

Although the incorporation of renewable energy sources into energy generation in Argentina has increased in recent years (Artola et al. 2019), they are still very underexploited. In the province of Cordoba, geothermal resources are also still underexploited, despite the fact that this energy source has numerous advantages, such as its

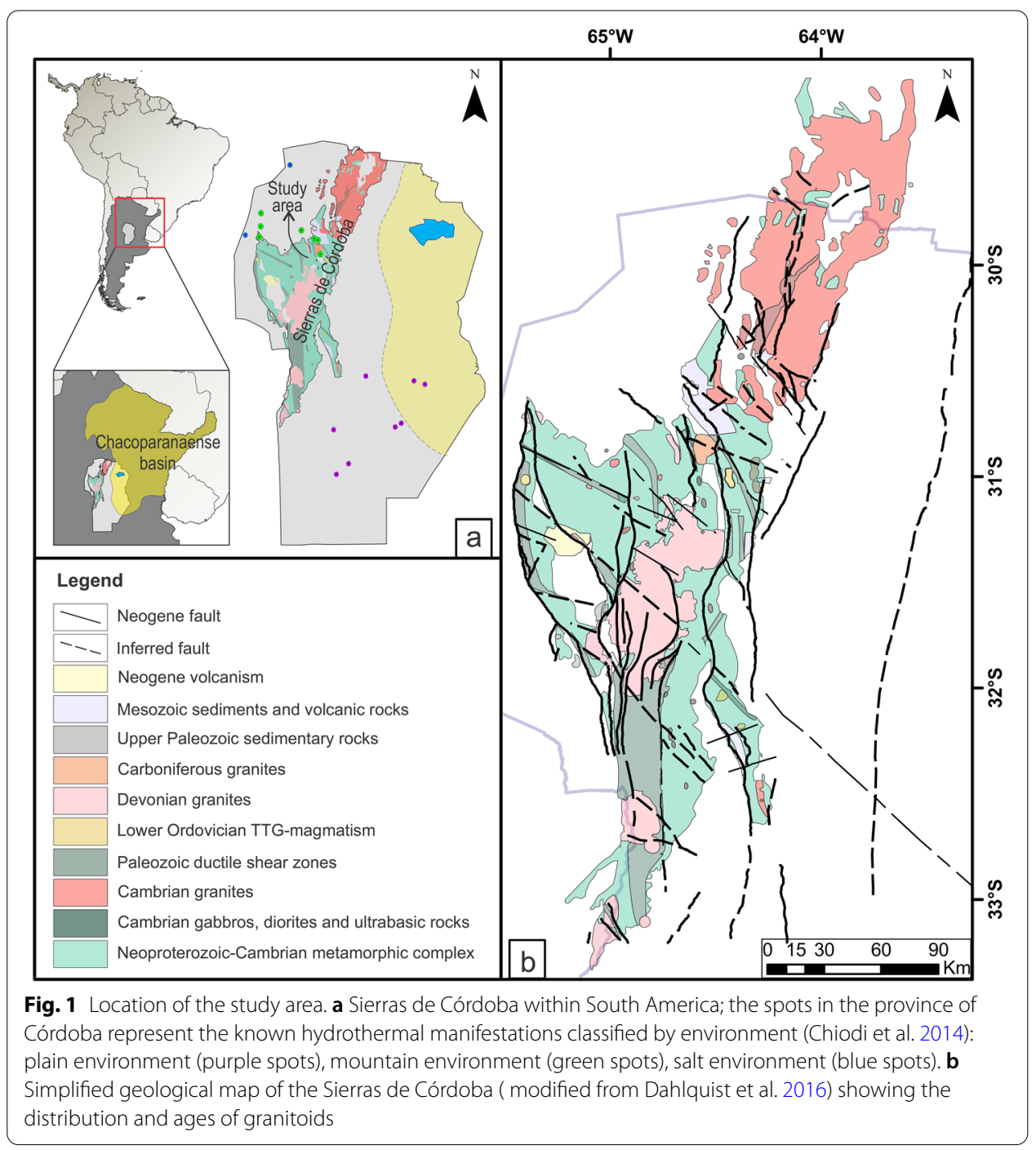


continuous supply of heat energy, its low or null emission of particles and gases, as well as the small surface area required for its development.

A key factor in long-term sustainable renewable energy projects is an assessment of the geothermal potential of the granitic bodies present in the Sierras de Córdoba, either for direct use purposes or those related to higher enthalpy, such as electric power generation. It should be noted that there are no available records of the study of heat production from granitic bodies in the Sierras de Córdoba. So far, the only reference has been by Coniglio (2006), who mentioned the heat production capacity of the Cerro Áspero and Achala batholiths due to their relatively high $\mathrm{K}$, Th and $\mathrm{U}$ contents, similar to that of HHP granites; he compared it to the Cornwall batholith (England) whose heat flow has been apparent for over $200 \mathrm{Ma}$ (Jackson et al. 1989). The reason why these bodies have not yet been more intensely studied from a petrothermal point of view is probably due to the absence of very high temperatures in the upper crust. Instead, efforts have been focused on exploring the traditional systems of high enthalpy with significant geothermal potential that occur in Argentina, related to the subduction of the Nazca plate beneath the Pacific plate.

The hydrothermal manifestations recognized in the province of Córdoba (with temperatures between 28 and $43^{\circ} \mathrm{C}$ ) are located in three different geotectonic environments (Chiodi et al. 2014): the plain environment, with manifestations in the southeast (Fig. 1a, purple spots), the mountain environment (Fig. 1a, green spots), and the salt environment (Fig. 1a, blue spots). The plain environment manifestations can be divided into two types: those related to Cretaceous depocenters, probably associated to areas with slightly anomalous gradients as a result of cortical thinning or the deep circulation of fluids through Cretaceous structures and sediments in normal gradients; and those located in the Chacoparanaense Basin, where Chiodi et al. (2014) propose an origin related to the discharge of deep aquifers belonging to the Paranaense Thermal System. For the manifestations located in the Sierras de Córdoba, Chiodi et al. (2014) suggest a possible deep circulation of fluids through Andean compressive structures in areas of normal geothermal gradient or in areas of anomalous geothermal gradient associated with Neogene activity. Some of the manifestations located in the Sierras de Córdoba are found on intrusions that are analyzed in this work as possible HHP granitoids, and are also close to structures linked to the Neogene activity recognized by Massabie (1987) and Massabie et al. (2003) for the Sierras Pampeanas Orientales.

\section{Geological setting}

The Sierras de Córdoba represent the easternmost range of the Sierras Pampeanas. Four main well-known orogenic episodes are recognized (Dahlquist et al. 2016), all of which have granitoid expressions: Pampean magmatism (555-515 Ma), Famatinian magmatism (484-463 Ma), Achalian magmatism (393-366 Ma) and early Carboniferous magmatism (357-322 Ma).

The major expression of Pampean magmatism is the Sierra Norte-Ambargasta batholith, with igneous exponents of diverse composition, although with a dominance of monzogranites, granodiorites and a dacite-rhyolite dome (Lira et al. 2014). Granodiorites, granites and subvolcanic porphyries are I-type metaluminous to weakly peraluminous in composition and have been interpreted as representing a Late Precambrian to Cambrian 
calc-alkaline magmatic arc that developed along the western margin of the Gondwana Supercontinent during the Pampean orogeny (Lira et al. 1997; Rapela et al. 1998; Leal et al. 2003; Miró et al. 2004; O’Leary et al. 2014).

The Famatinian magmatism in the Sierras de Córdoba is dominated by a TTG-type magmatism (trondhjemite-tonalite-granodiorite association), characterized by Rapela et al. (1998). Its expressions are slightly to moderately peraluminous, enriched in $\mathrm{Na}_{2} \mathrm{O}$, $\mathrm{Ca}_{2} \mathrm{O}$ and $\mathrm{Sr}$, and strongly depleted in $\mathrm{K}_{2} \mathrm{O}, \mathrm{FeO}_{\mathrm{t}}, \mathrm{Y}, \mathrm{Cs}$ and $\mathrm{U}$. They are related to an internal magmatic arc located on the pampa basement of the western margin of Gondwana, which is contemporaneous with the main Famatinian magmatic arc located further west (D'Eramo et al. 2014). The magmatism is expressed as small plutons with circular or elliptical shapes. The TTG magmatism (especially in its trondhjemitic units) has geochemical characteristics that suggest a deep magmatic source with possible mantle linkage (D'Eramo et al. 2014).

The Devonian magmatism in the Sierras de Córdoba is expressed by a series of different-sized bodies, some of them large, with a discordant disposition in relation to the older crustal rocks. The Cerro Áspero batholith is mostly composed of monzogranites, and is made up of three main plutons with a NNW alignment known as Alpa Corral, El Talita and Los Cerros. It is the product of the evolution of granitic magmatism with a high $\mathrm{K}_{2} \mathrm{O}$ content, in which the less evolved rocks are similar to calc-alkaline granites, with $\mathrm{SiO}_{2}$ values between 65 and 71\%, and the more evolved rocks show a strong affinity with A-type granites, with $\mathrm{SiO}_{2}$ values higher than $76 \%$ and increasing peraluminosity and alkalinity in the same way (Pinotti et al. 2014).

Other Devonian expressions (located to the south of this batholith) are the Achiras Complex and the Inti Huasi granite. The Inti Huasi granite is ovoid in shape with an axis greater than $20 \mathrm{~km}$ in an easterly direction (determined through geophysical studies by Sims et al. 1998). It is mostly buried under quaternary sediments of piedmont, emerging in a discontinuous way (total surface of $3.5 \mathrm{~km}^{2}$ ), and is discordant with the host rock (Otamendi et al. 2014). It is dominated by slightly peraluminous monzogranites, and was generated by a magma with cortical sources involving intermediate plutonic rocks (Otamendi et al. 2014). Its geochemical features exclude it from being considered S-type granite sensu stricto (Clemens 2003).

The Achala batholith has a surface area of nearly $2,500 \mathrm{~km}^{2}$. It is considered the result of aluminous A-type magmatism, emphasizing the higher content of aluminosity in comparison with authentic alkaline A-type granites (Lira and Sfragulla 2014). The predominant lithologies are muscovite-biotite monzogranites, and its potassium-rich chemistry classifies it as a calc-alkaline to alkali-calcic granite, with $\mathrm{SiO}_{2}$ contents varying between 60 and 76\% (Lira and Sfragulla 2014). An exceptional feature of this body is the presence of cumulates, or Bt-Ap-rich bodies. Lira (1985, 1987), and Lira and Kirschbaum (1990) provide a general description of these Bt-Ap-rich bodies and emphasize their high content of radioactive minerals, describing them as erratically distributed within the dominant porphyritic monzogranite facies. Dorais et al. (1997) made a detailed study of the geology, mineralogy and geochemistry of these bodies, assigning all of them to the regional porphyritic facies (Achala series by Demange et al. 1996). Bt-Ap-rich bodies are defined as tabular and elongated, with lengths from less than one meter to tens of meters, and thicknesses of up to $10 \mathrm{~m}$ (Lira and Sfragulla 2014). This magmatism is 
accompanied by a series of smaller plutons, which are assigned to the same event (Lira and Sfragulla 2014) due to their geochemical and mineralogical characteristics, and other indicators such as their age and associated mineralization.

The Capilla del Monte pluton, although assigned to Achalian magmatism by different authors (including Lira and Sfragulla 2014), is assigned by Dahlquist et al. (2016) to an early Carboniferous magmatism (357-322 Ma) based on a zircon crystallization age dating of $336 \pm 3 \mathrm{Ma}$. This age places the Capilla del Monte pluton as the easternmost member of the early Carboniferous A-type magmatic event. This pluton has an oval shape and is discordant in relation to the host rock. It is partially covered by Tertiary and Quaternary sediments, product of the mid-late Pleistocene mega-landslide of Cerro Uritorco (Carignano et al. 2014). The same reasoning applies to the Serrezuela pluton, although Dahlquist et al. (2013) suggest that this body also belongs to a different cycle than Achalian magmatism, and should be assigned to a later event.

\section{Materials and methods}

The concentrations of $\mathrm{U}$, Th and $\mathrm{K}_{2} \mathrm{O}$, the $\mathrm{SiO}_{2}$ content, geolocation of the sample, pluton or batholith name, lithological type and crystallization ages of the granitic bodies of the Sierras de Córdoba are shown in Additional file 1: Table S1. The data used in this paper have been compiled from available published literature corresponding to researchers that surveyed the area for different purposes commonly related to unraveling the geological history of the Sierras de Córdoba, and published data from the Servicio Geológico Minero Argentino (SEGEMAR), who carried out a survey during 1995 and 1996 with the aim of mapping of the Sierras Septentrionales de Córdoba within the framework of the "Geoscientific Mapping of the Sierras Pampeanas Argentina-Australia Cooperative Project" (AGSO-SEGEMAR). The methods used for determining whole-rock geochemistry were X-ray fluorescence spectrometry (XRF 80\%) and inductively coupled plasma optical emission spectroscopy (ICP-OES $\sim 20 \%$ ) for major elements, and Inductively coupled plasma mass spectrometry (ICP-MS 55\%), XRF ( 33\%) and instrumental neutron activation analysis (INAA $\sim 12 \%)$ for rare earth and trace elements. The database has 183 entries. From the compiled data, the heat production rate (A) was obtained for each sample, based on Rybach's Eq. (1988):

$$
A\left(\frac{\mu W}{m^{3}}\right)=10^{-2} * \rho *\left(9.52 C_{U}+2.56 C_{T h}+3.48 C_{K}\right),
$$

where $\rho\left(\mathrm{g} / \mathrm{cm}^{3}\right)$ is the density of the rock, and $\mathrm{C}_{\mathrm{U}}, \mathrm{C}_{\mathrm{Th}}$ and $\mathrm{C}_{\mathrm{K}}$ are the concentrations of uranium (ppm), thorium (ppm) and potassium (\%), respectively. $\mathrm{C}_{\mathrm{K}}$ is expressed as a percentage of elemental potassium (or $\mathrm{K}_{2} \mathrm{O}$ multiplied by 0.83 ). An average density of $2.677 \mathrm{~g} / \mathrm{cm}^{3}$ was used for granitoids (Zhou et al. 2020). As demonstrated by Artemieva et al. (2017), a density variation of 2.7 to $2.65 \mathrm{~g} / \mathrm{cm}^{3}$ will produce an uncertainty in the heat production rate of approximately $2 \%$. Also, uncertainties in the concentrations of $\mathrm{U}$, Th and K will produce an error of 2 to 10\% (determined by Ashwal et al. 1987 in a regional study of the Canadian craton).

According to Zhou et al. (2020), the magnitude of radioactive heat production per year for a given intrusion can be estimated with the following equation: 


$$
Q\left(\frac{J}{y}\right)=A *(\rho * S * T) * 10^{15} * 10^{-6}
$$

where $\mathrm{Q}$ is the heat reservoir per year $(\mathrm{J} / \mathrm{y}) ; \mathrm{A}(\mu \mathrm{J} / \mathrm{g} . \mathrm{y})$ represents the radiogenic heat production; $\rho\left(\mathrm{g} / \mathrm{cm}^{3}\right)$ is the density of the intrusion; $S\left(\mathrm{~km}^{2}\right)$ is the surface area of the outcrop; and $\mathrm{T}(\mathrm{km})$ is the thickness of the intrusion. Very few data are available on the three-dimensional shapes of plutons in the Sierras de Córdoba. Only four intrusions have geophysical data that reveal their entire geometry (see Additional file 1: Table S2). However, if the intrusion has not undergone significant tectonic changes, its thickness can be estimated from its original geometry and from consideration of the amount of material that has been eroded since the emplacement (Mc Caffrey and Petford 1997). In this work, the original geometry of each pluton has been estimated considering the surface outcrops and according to the empirical power-law of pluton dimensions proposed by Mc Caffrey and Petford (1997) and Cruden and Mc Caffrey (2001). These authors, based on field and geophysical measurements, suggest that the growth of a laterally spreading (L) and vertically thickening ( $\mathrm{T}$ ) intrusive flow evolves according to a powerlaw (self-affine) relationship of the form $\mathrm{T}=k L^{a}$, typically of systems exhibiting scaleinvariant (fractal) behavior (Petford et al. 2000). According to Cruden and Mc Caffrey (2001), the values of the coefficients " $k$ " and "a" for plutons are equal to $k=0.6 \pm 0.15$ and $\mathrm{a}=0.6 \pm 0.1$. The tectonic deformation and the degree of erosion of each intrusion has been determined based on geological observations published by several authors (age of crystallization, magmatic event, emplacement model, lithology, petrography, structures, mineralization, among others). Although some plutons show signs of deformation after emplacement (e.g., foliations, crystal deformation, brittle structures), no significant signs of deformation have been reported for most of the intrusions. In addition, it is considered that the reported tectonic deformations do not have a significant impact on the dimensions of the plutons according to the working scale considered in the present study. The degree of erosion has been taken into account considering two possible scenarios: (1) low erosion (level of erosion at the top of the intrusion): the degree of erosion is negligible and most of the intrusive roof is preserved. No erosion correction is applied to the estimated thickness; (2) middle erosion (erosion level in the middle zone of the intrusion): the degree of erosion is moderate and the roof of the intrusive is not preserved. A correction coefficient equal to 0.5 is applied to the estimated thickness. From the results obtained (Additional file 1: Table S2), it can be seen that there is a good correlation between the thicknesses estimated using the erosion-corrected power-law and the geophysical models.

The alphabetical S-I-A-M classification is applied in this work (Table 1) to observe trends between the radiogenic heat production and the petrogenetic granite type, since it is based on geochemical variations typical of certain settings sources and/ or formational processes. However, it must be taken into account that there is a huge controversy regarding the granite-type in some of the studied granitoids (either due to inconsistencies or to a lack of data), particularly in the Achala batholith. Instead, a consensus has been achieved with the information available to date (Lira and Sfragulla 2014). This alphabetical classification has been applied worldwide, as it would seem simple to distinguish the origin of the granitoid; however, it does not take 
Pleitavino et al. Geotherm Energy

(2021) 9:16

Page 8 of 24

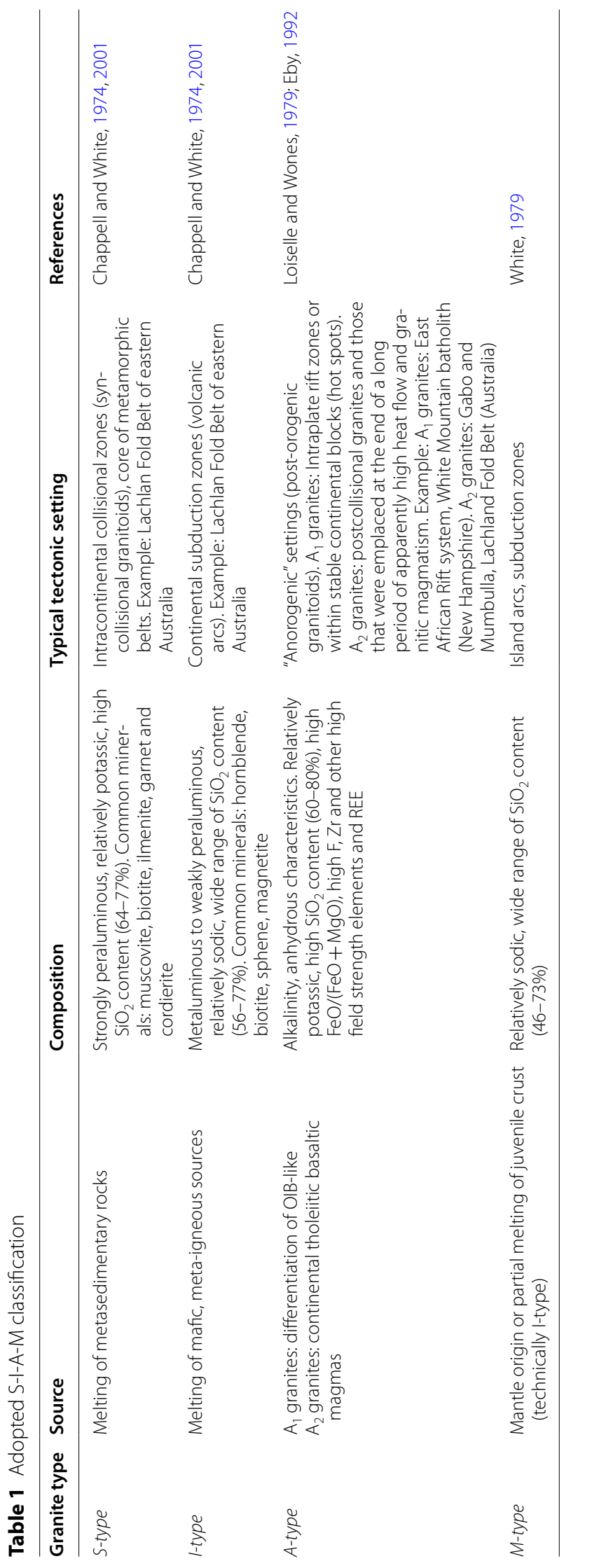


into account that a granite rarely is derived from a single source, and that several different origins can reach a similar granitic composition (Frost et al. 2001).

\section{Results and discussion}

Heat production analysis

The average concentrations of $\mathrm{U}$, Th and $\mathrm{K}$, and the $\mathrm{Th} / \mathrm{U}$ and $\mathrm{K} / \mathrm{U}$ ratios with their standard deviations for the Sierras de Córdoba granitoids are presented in Table 2.

The highest mean concentrations of $\mathrm{U}$ were obtained in the Capilla del Monte pluton $(8.29 \pm 3.48 \mathrm{ppm})$, and those of $\mathrm{Th}$ and $\mathrm{K}$ were obtained in the Cerro Áspero batholith (33.40 $\pm 25.02 \mathrm{ppm}$ and $4.31 \pm 0.43 \%$, respectively), although with low representativeness due to the number of samples $(\mathrm{N}=5)$, followed by the Achala batholith $(30.35 \pm 23.57 \mathrm{ppm}$ for Th and $4.17 \pm 0.49 \%$ for K). The Güiraldes, La Fronda and San Agustín plutons differ from the rest due to the low concentrations of these three elements, in line with a magmatism described as having TTG-type features. The average concentrations of the heat-producing elements for the granitic rocks of the Sierras de Córdoba are $3.78 \pm 2.33 \mathrm{ppm}, 16.60 \pm 10.49 \mathrm{ppm}$ and $2.97 \pm 0.42 \%$ for $\mathrm{U}$, Th and $\mathrm{K}$, respectively; these values are slightly different from those obtained by Artemieva et al. (2017) for the granitic rocks in their global database, with averages of $3.93 \pm 3.27 \mathrm{ppm}$, $14.8 \pm 13.2 \mathrm{ppm}$ and $2.79 \pm 1.44 \%$ for $\mathrm{U}$, Th and $\mathrm{K}$, respectively.

The mean value of the $\mathrm{Th} / \mathrm{U}$ ratio for the granitic rocks of the Sierras de Córdoba is $7.27 \pm 6.09$, slightly higher than the mean values reported for the continental crust (Th/ $\mathrm{U}=3.8$ according to McLennan et al. 1980; up to Th/U $=5$ according to Wedepohl 1995). Values out of this range could indicate isotope mobilization processes, particularly of $\mathrm{U}$ in its oxidized state; however, the deviation is too high to draw any firm conclusions. The K/U ratio $\left(1.64 \times 10^{4} \pm 1.26 \times 10^{4}\right)$ is close to the expected value for an average

Table 2 Mean values of $U$ (ppm), Th (ppm) and $\mathrm{K}(\%)$, and Th/U and K/U ratios and their standard deviations for granite plutons in the Sierras de Córdoba

\begin{tabular}{|c|c|c|c|c|c|c|}
\hline Granitoid & No. of samples & $\mathrm{U}(\mathrm{ppm})$ & Th (ppm) & $\mathrm{K}(\%)$ & $\mathrm{Th} / \mathrm{U}$ & $K / U$ \\
\hline Achala batholith $(A B)$ & 36 & $5.89 \pm 4.16$ & $30.35 \pm 23.57$ & $4.17 \pm 0.49$ & $6.02 \pm 5.53$ & $0.90 \pm 0.35$ \\
\hline $\begin{array}{l}\text { Capilla del Monte pluton } \\
\text { (CMP) }\end{array}$ & 10 & $8.29 \pm 3.48$ & $29.96 \pm 21.26$ & $3.99 \pm 0.58$ & $4.41 \pm 3.54$ & $0.55 \pm 0.22$ \\
\hline $\begin{array}{l}\text { Cerro Aspero batholith } \\
\text { (CAB) }\end{array}$ & 5 & $4.00 \pm 2.12$ & $33.40 \pm 25.02$ & $4.31 \pm 0.43$ & $9.77 \pm 6.50$ & $1.36 \pm 0.68$ \\
\hline Inti Huasi granite (IGG) & 7 & $3.90 \pm 0.78$ & $14.36 \pm 7.92$ & $3.98 \pm 0.15$ & $3.54 \pm 1.53$ & $1.06 \pm 0.24$ \\
\hline $\begin{array}{l}\text { Loma de la Población } \\
\text { pluton (LOPP) }\end{array}$ & 4 & $7.50 \pm 6.56$ & $16.25 \pm 7.89$ & $3.80 \pm 0.08$ & $3.36 \pm 2.06$ & $0.87 \pm 0.70$ \\
\hline Serrezuela pluton (SP) & 13 & $5.36 \pm 4.19$ & $27.79 \pm 14.57$ & $3.97 \pm 0.67$ & $8.56 \pm 6.12$ & $1.73 \pm 1.82$ \\
\hline La Playa pluton (LPP) & 16 & $2.23 \pm 1.45$ & $5.64 \pm 3.46$ & $2.52 \pm 0.79$ & $3.23 \pm 2.49$ & $1.57 \pm 0.88$ \\
\hline Güiraldes pluton (GP) & 9 & $0.62 \pm 0.40$ & $5.41 \pm 2.25$ & $1.46 \pm 0.31$ & $13.75 \pm 14.41$ & $3.64 \pm 3.84$ \\
\hline La Fronda pluton (LFP) & 4 & $0.33 \pm 0.21$ & $3.98 \pm 0.75$ & $0.76 \pm 0.14$ & $19.13 \pm 17.49$ & $3.60 \pm 3.18$ \\
\hline San Agustín pluton (SAP) & 3 & $0.60 \pm 0.10$ & $0.77 \pm 0.31$ & $0.55 \pm 0.03$ & $1.25 \pm 0.29$ & $0.93 \pm 0.11$ \\
\hline $\begin{array}{l}\text { Sierra Norte batholith } \\
\text { (SNB) }\end{array}$ & 57 & $2.89 \pm 2.19$ & $14.75 \pm 8.38$ & $3.15 \pm 0.90$ & $6.94 \pm 7.02$ & $1.79 \pm 1.89$ \\
\hline Mean value & $164^{*}$ & $3.78 \pm 2.33$ & $16.60 \pm 10.49$ & $2.97 \pm 0.42$ & $7.27 \pm 6.09$ & $1.64 \pm 1.26$ \\
\hline
\end{tabular}

* Number of samples analyzed for the determination of mean values. Anomalous heat production values are excluded in the determination of the means. From all the samples in the database $(N=183)$, anomalous values of Bt-Ap-rich bodies from the Achala batholith, anomalous values of two samples from Sierra Norte, and samples from the Paso del Carmen tonalite and the Agua de Ramón pluton (because there was only one sample of each) were excluded 
continental crust $\left(1.0 \times 10^{4}\right.$ according to Wasserberg et al. $1964 ; 1.2 \times 10^{4}$ according to Wedepohl 1995).

The average heat production rate values (A) for each element, as well as the average heat production with standard deviations for each granitoid in the Sierras de Córdoba, and the relative contributions of the elements are presented in Table 3. The mean contribution of Th is dominant (46.24\%), followed by $\mathrm{U}$ (39.55\%), with a lower participation for $\mathrm{K}(14.21 \%)$.

Some of the samples compiled in the database lack precise spatial references, thereby their locations are approximate (to identify the samples, consult Additional file 1: Table S1). Interpretations that include the distribution of individual data must be understood with this in mind. Figure 2 shows the distribution of heat production (A) for each sample and the mean heat production for each granitoid (detailed in Table 2). All granitoids representing the Achalian and early Carboniferous magmatic events have higher values than the mean A value of $2.0 \mu \mathrm{W} / \mathrm{m}^{3}$ determined by Artemieva et al. (2017), and those assigned to the Famatinian event are lower. The average heat production (A) for the Sierra Norte batholith (Pampean magmatic event) is slightly more than $2.0 \mu \mathrm{W} / \mathrm{m}^{3}$.

McCay and Younger (2017), stablish that granites with a radiogenic heat production above $5.00 \mu \mathrm{W} / \mathrm{m}^{3}$ are considered HHP granites, granites with values between $5.00 \mu \mathrm{W} / \mathrm{m}^{3}$ and $3.00 \mu \mathrm{W} / \mathrm{m}^{3}$ are considered MHP granites and the ones with a value below $3.00 \mu \mathrm{W} / \mathrm{m}^{3}$ are considered LHP granites. According to this classification, five granitoids fall into the range of MHP granites: Capilla del Monte pluton, Achala batholith, Cerro Áspero batholith, Serrezuela pluton and Loma de la Población pluton. These plutons could be viable geothermal resources if a heat-demanding development were proposed within close proximity to these granites and as a supply for any future large heat demand. The Inti Huasi granite, Sierra Norte batholith, La Playa pluton, Güiraldes

Table 3 Mean heat production values (A) with standard deviation and contributions of each element

\begin{tabular}{|c|c|c|c|c|c|c|c|c|}
\hline \multirow[t]{2}{*}{ Body } & \multirow[t]{2}{*}{ No. of samples } & \multicolumn{4}{|c|}{$A\left(\mu W / m^{3}\right)$} & \multicolumn{3}{|c|}{ Contributions (\%) } \\
\hline & & $\mathbf{U}$ & Th & $\mathrm{K}$ & Total & $\bar{U}$ & Th & $\mathrm{K}$ \\
\hline Achala batholith $(A B)$ & 36 & 1.50 & 2.08 & 0.39 & $3.97 \pm 2.18$ & 37.83 & 52.40 & 9.78 \\
\hline Capilla del Monte pluton (CMP) & 10 & 2.11 & 2.05 & 0.37 & $4.54 \pm 1.38$ & 46.55 & 45.26 & 8.19 \\
\hline Cerro Aspero batholith (CAB) & 5 & 1.02 & 2.29 & 0.40 & $3.71 \pm 1.85$ & 27.48 & 61.70 & 10.82 \\
\hline Inti Huasi granite (IGG) & 7 & 0.99 & 0.98 & 0.37 & $2.35 \pm 0.71$ & 42.32 & 41.90 & 15.78 \\
\hline Loma de la Población pluton (LOPP) & 4 & 1.91 & 1.11 & 0.35 & $3.38 \pm 1.66$ & 56.56 & 32.96 & 10.48 \\
\hline Serrezuela pluton (SP) & 13 & 1.37 & 1.90 & 0.37 & $3.64 \pm 1.78$ & 37.53 & 52.32 & 10.15 \\
\hline La Playa pluton (LPP) & 16 & 0.57 & 0.39 & 0.23 & $1.19 \pm 0.50$ & 47.79 & 32.50 & 19.71 \\
\hline Güiraldes pluton (GP) & 9 & 0.16 & 0.37 & 0.14 & $0.67 \pm 0.22$ & 23.83 & 55.72 & 20.46 \\
\hline La Fronda pluton (LFP) & 4 & 0.08 & 0.27 & 0.07 & $0.43 \pm 0.09$ & 19.44 & 63.95 & 16.60 \\
\hline San Agustín pluton (SAP) & 3 & 0.15 & 0.05 & 0.05 & $0.26 \pm 0.05$ & 59.56 & 20.47 & 19.97 \\
\hline Sierra Norte batholith (SNB) & 57 & 0.74 & 1.01 & 0.29 & $2.04 \pm 0.93$ & 36.13 & 49.52 & 14.36 \\
\hline Mean value & $164^{*}$ & 0.96 & 1.14 & 0.28 & $2.38 \pm 1.03$ & 39.55 & 46.24 & 14.21 \\
\hline
\end{tabular}

Heat production per element and total radiogenic heat production rate (A) of the Sierras de Córdoba granitoids and their standard deviation. Contributions of $\mathrm{U}, \mathrm{Th}$ and $\mathrm{K}$ to the heat production

*Number of samples analyzed for the determination of mean values. Anomalous heat production values are excluded in the determination of the means. From all the samples in the database $(N=183)$, anomalous values of Bt-Ap-rich bodies from the Achala batholith, anomalous values of two samples from Sierra Norte, and samples of the Paso del Carmen tonalite and the Agua de Ramón pluton (because there was only one sample of each) were excluded 


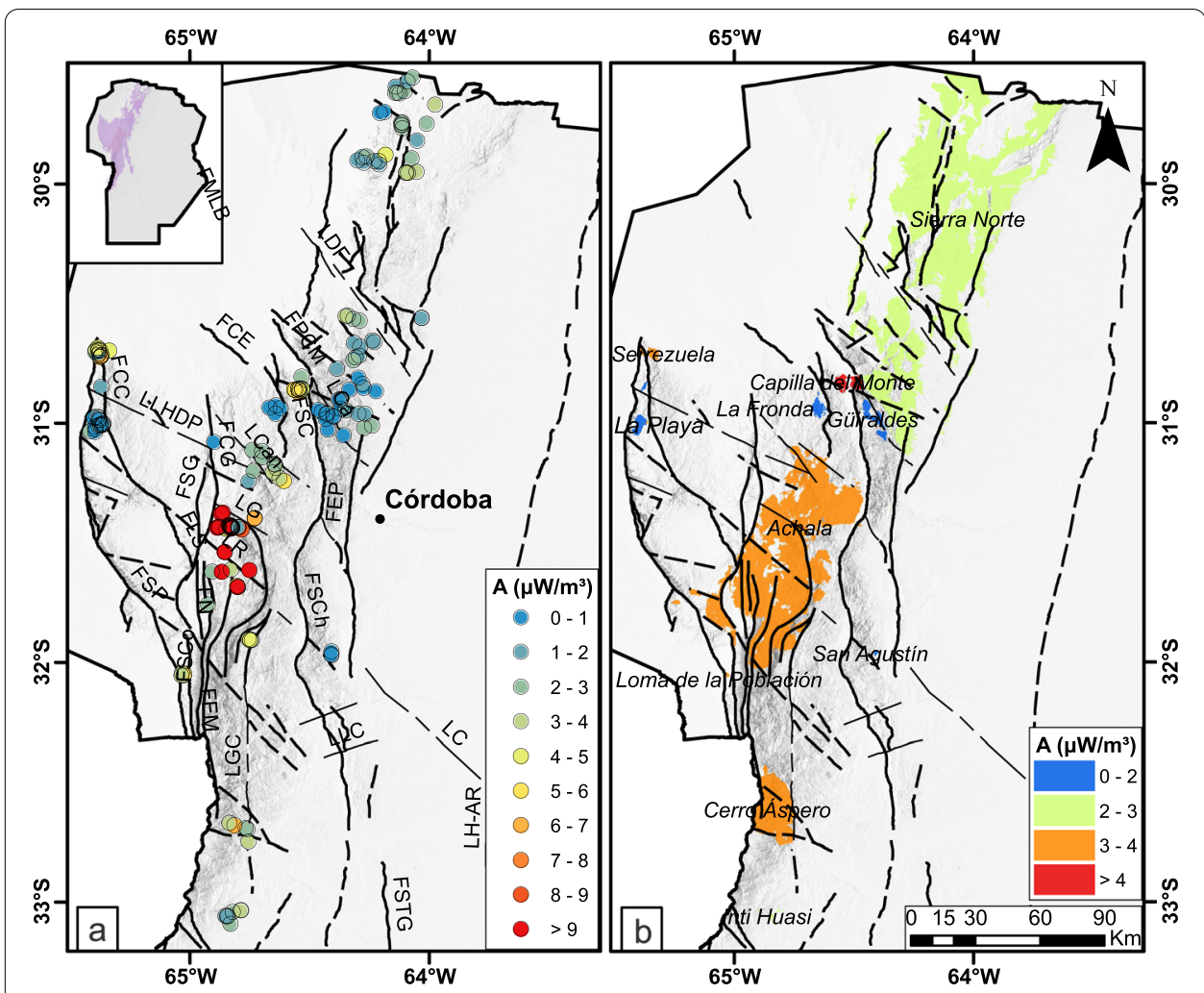

Fig. 2 a Radiogenic heat production value $\left(\mu \mathrm{W} / \mathrm{m}^{3}\right)$ for each sample in the Sierras de Córdoba. The solid and intermittent lines correspond to the known and/or inferred faults and lineaments in the Sierras de Córdoba: Ciénaga del Coro fault (FCC), Cruz del Eje fault (FCE), Cumbres de Gaspar fault (FCG), El Molino fault (FEM), Elevación Pampeana fault (FEP), Las Lagunas fault (FLL), Lagunilla del Plata fault (FLP), La Sierrita fault (FLS), Monte de Las Barrancas fault (FMLB), Nono's fault (FN), Pajarillo-Copacabana-Masa fault (FPCM), Saladillo's fault (FS), Sierra de Cuniputo's fault (FSC), Sierra Chica fault (FSCh), Sierra de Comechingones fault (FSCo), Sierra Grande fault (FSG), Sierra de Pocho fault (FSP), Sierra del Tigre Muerto fault (FSTG), Tostado-Selva fault (FTS), Balnearia lineament (LB), Chazón lineament (LC), Carapé lineament (LCa), Candelaria lineament (LCan), Corral de Carnero lineament (LCC), Deán Funes lineament (LDF), Guasta lineament (LG), Guacha Corral lineament (LGC), Hernando-Alejandro Roca lineament (LH-AR), Los Cóndores lineament (LLC), La Higuera-Dos Pozos lineament (LLHDP), Quebrada Honda lineament (LQH), Retamito lineament (LR), Ranqueles-Isla Verde lineament (LR-IV), Río Dulce lineament (LRD), Rincón Grande lineament (LRG). b Granitoids studied in the Sierras de Córdoba and their mean values of radiogenic heat production rate $\left(\mu \mathrm{W} / \mathrm{m}^{3}\right)$

pluton, La Fronda pluton and San Agustín pluton had LHP values, therefore it is unlikely that these granites provide geothermal gradients of interest for direct economic use of the heat. In addition, the Capilla del Monte pluton $\left(4.54 \mu \mathrm{W} / \mathrm{m}^{3}\right)$ should be considered a potential resource as a marginally HHP because it is just slightly below the threshold to be considered an HHP. To give a more robust value for Capilla del Monte pluton it is essential to expand the database, in order to validate its category as an MHP or to adjust this one to an HHP.

Figure 3 shows the spatial variability in the concentrations of U, Th and K in the Sierras de Córdoba. Analyzing each granitoid individually, the values are within limited ranges, except for a few samples. Heat production (A) reflects the distribution patterns of $U$ and Th concentrations, since they release more energy during their decay. The lowest heat production values $\left(\mathrm{A}<2.00 \mu \mathrm{W} / \mathrm{m}^{3}\right)$ are concentrated in Sierra Norte and in the sparse manifestations of the Ordovician; and the highest values $\left(\mathrm{A}>4.00 \mu \mathrm{W} / \mathrm{m}^{3}\right)$ are mainly 


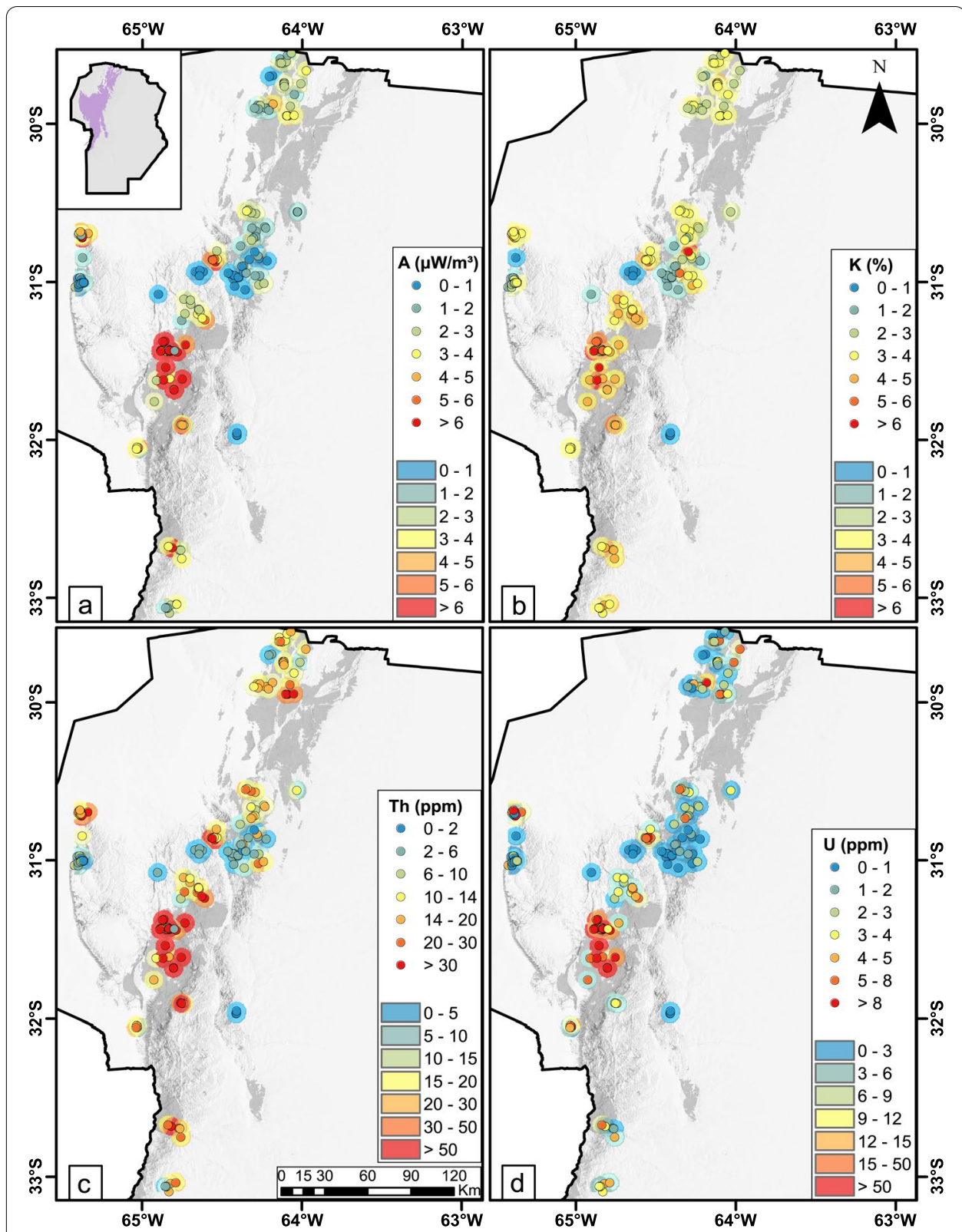

Fig. 3 Samples with their values (each spot) and IDW interpolation (background shading), proposed by Rybach (1988) as the most appropriate interpolation for any variable related to heat production and geothermal mapping. a Radiogenic heat production $\left(\mu \mathrm{W} / \mathrm{m}^{3}\right)$. b Concentrations of $\mathrm{K}(\%)$. c Concentrations of Th (ppm). $\mathbf{d}$ Concentrations of $U$ (ppm)

found in Achala and in other smaller areas such as Capilla del Monte, Serrezuela and Cerro Áspero.

Since radioactive decay leads to a secular decrease in radiogenic heat in the Earth, it may also lead to a secular decrease in the concentration of radiogenic elements in the continental crust and granitic rocks, with the oldest rocks having the lowest concentrations (Artemieva et al. 2017). In the Sierras de Córdoba, the decrease of the radiogenic heat production for the different magmatic events is similar, varying between $3.12 \%$ and $4.43 \%$ (Table 4). This suggests that the geological age of each magmatic event does 


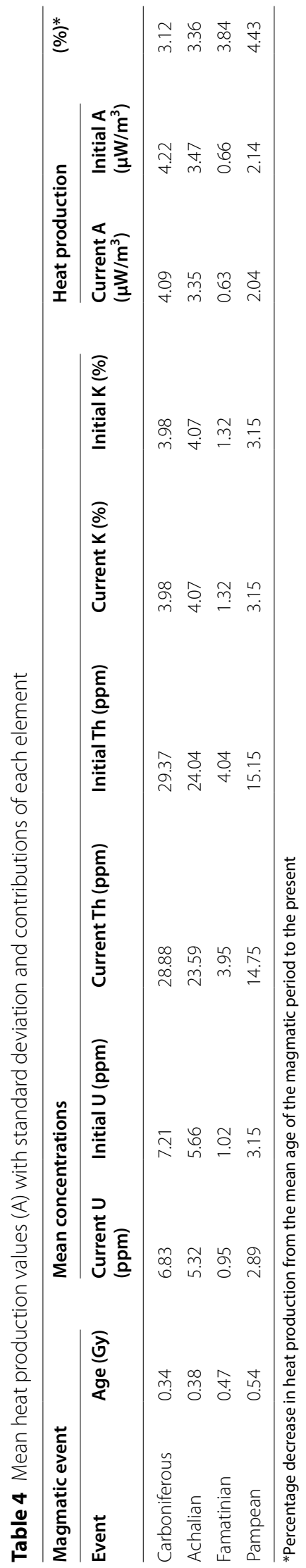


not have major influence on the thermal response of the different lithologies, since the period of time for the magmatic events in the Sierras de Córdoba is narrow in comparison with the half-life of the main heat-producing isotopes of each element $\left(4.47 \times 10^{9} \mathrm{y}\right.$ for ${ }^{238} \mathrm{U}$ and $7.04 \times 10^{8} \mathrm{y}$ for ${ }^{235} \mathrm{U}, 1.41 \times 10^{10} \mathrm{y}$ for ${ }^{232} \mathrm{Th}$ and $1.28 \times 10^{9} \mathrm{y}$ for ${ }^{40} \mathrm{~K}$ ).

In contrast, the differences in the radiogenic heat production between magmatic events could be related to the origin and tectonic setting of granite rocks (Fig. 4), which will affect their chemical composition and the concentrations of radioactive elements (Kemp 2001; Kemp and Hawkesworth 2003). So far, the results indicate that only A-type granitoids could be classified as HHP or MHP granitoids, even though they show a high variability of radiogenic heat production. On the other hand, the lowest values correspond to TTG-type granitoids, assigned to the Famatinian magmatic event. Lowto-medium values are associated with an S-type magmatism assigned to Famatinian magmatism, and with an I-type magmatism assigned to Pampean magmatism, although some of these samples represent younger ages. In summary, this can be understood as being a result of the differentiation of the crust over time, dragging higher relative concentrations of incompatible elements towards the most external part of the Earth and as the result of the contamination with crust material of the magmas that gave rise to the A-type intrusions, from re-melting and specializations during their formation.

As previously mentioned, the intraplate geothermal regime is related to the concentration of radiogenic elements and their heat production; and because these elements have an affinity with bodies with a higher $\mathrm{SiO}_{2}$ content, the granitoids from the upper crust will be the main carriers of these radiogenic elements (Artemieva et al. 2017). In areas with relatively stable tectonics such as the Sierras de Córdoba, spatial variations in surface heat flow should be understood as derived mainly from radiogenic heat production. The normal trend for the radiogenic heat production vs. $\mathrm{SiO}_{2}$ content (Fig. 5a), as presented and discussed by Siegel et al. (2011) for North America and Queensland (Australia), is to find high concentrations of radiogenic elements associated with high

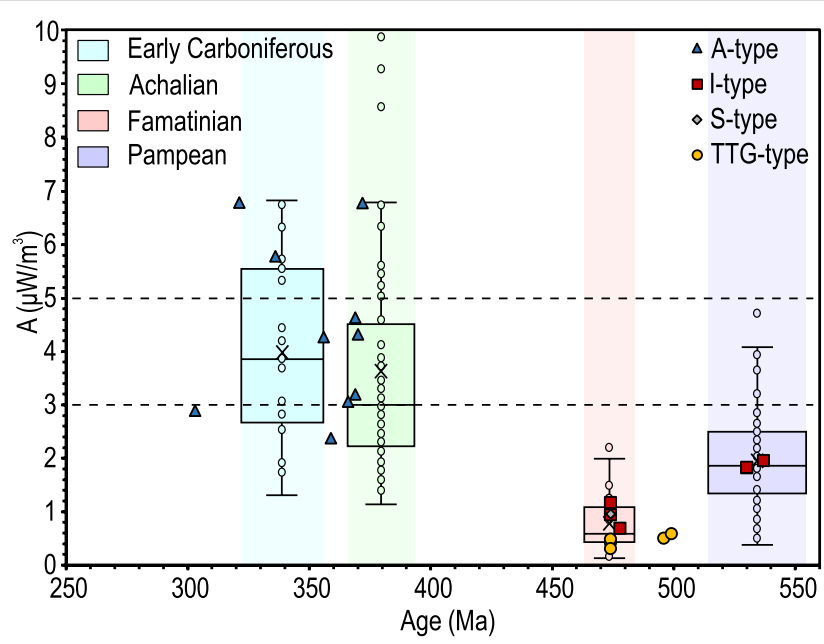

Fig. 4 Box plots of heat production of granitic rocks according to their magmatic event. The point shapes correspond to the heat production for samples with crystallization age data based on U-Pb in zircon, classified by tectonic type (S-I-A-M classification) 

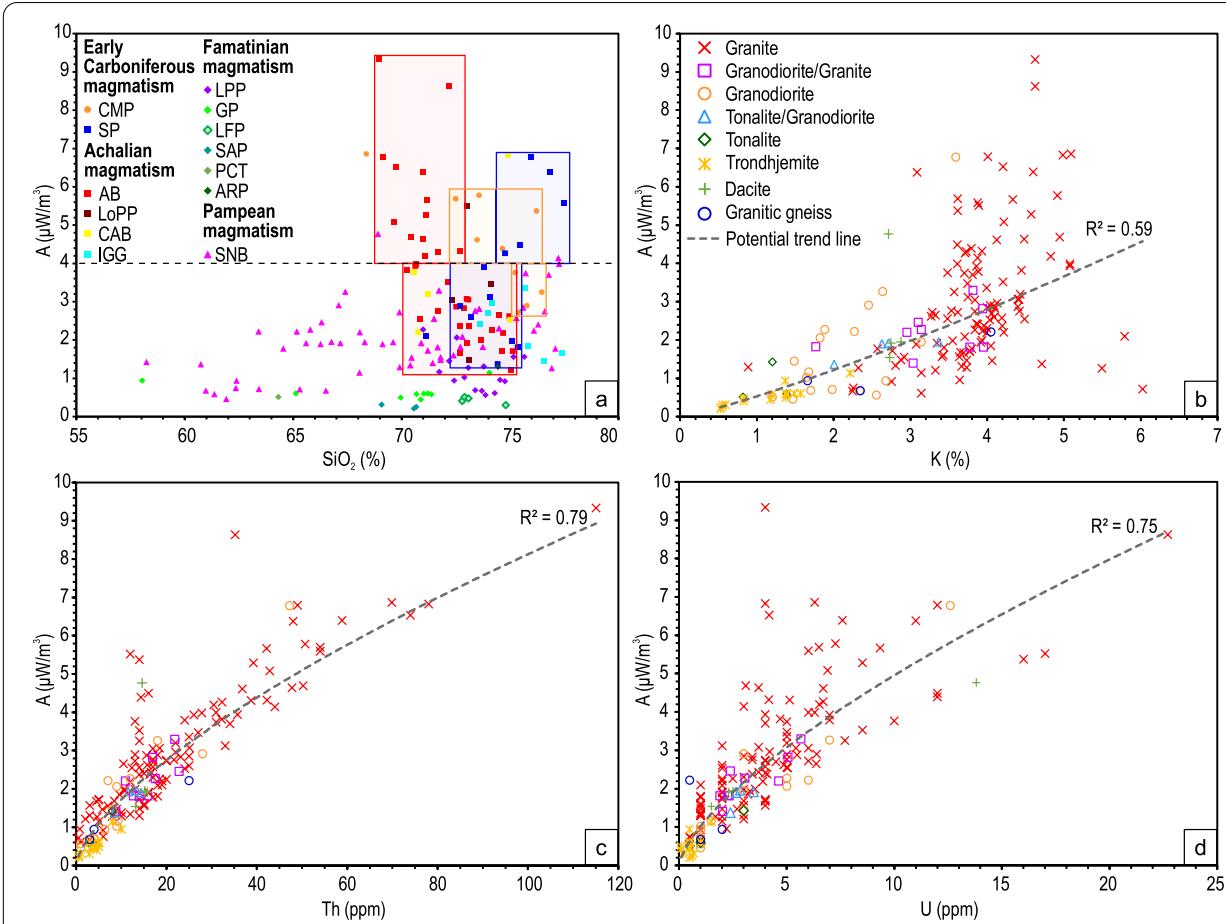

Fig. 5 a $A\left(\mu W / m^{3}\right)$ vs. $\mathrm{SiO}_{2}$ content (\%) for each intrusion. b $\mathrm{A}\left(\mu \mathrm{W} / \mathrm{m}^{3}\right)$ vs. $\mathrm{K}(\%)$ for the different lithologic types. $\mathbf{c} A\left(\mu \mathrm{W} / \mathrm{m}^{3}\right)$ vs. Th $(\mathrm{ppm})$ for the different lithologic types. $\mathbf{d} \mathrm{A}\left(\mu \mathrm{W} / \mathrm{m}^{3}\right)$ vs. $\mathrm{U}(\mathrm{ppm})$ for the different lithologic types

concentrations of $\mathrm{SiO}_{2}$ (with $\mathrm{SiO}_{2}>70 \%$ ). For those locations, the authors indicate an increase in heat production for $\mathrm{SiO}_{2}$ values between 75 and 78\%. However, not all rocks with high $\mathrm{SiO}_{2}$ contents are high heat producers, and the same authors report extreme fluctuations of A, from about $0.00 \mu \mathrm{W} / \mathrm{m}^{3}$ to $25.00 \mu \mathrm{W} / \mathrm{m}^{3}$. Considering a heat production threshold of $4.00 \mu \mathrm{W} / \mathrm{m}^{3}$, our database shows higher heat production in samples with $\mathrm{SiO}_{2}$ contents between 68 and 78\%, although lower values can also be observed for the same range. The trend of high production with $\mathrm{SiO}_{2}(\%)$ content analyzed for the main intrusions also changes. In the Achala batholith, heat production values above the threshold have $\mathrm{SiO}_{2}$ contents between 69 and 73\%, with a decreasing trend for contents between 70 and $75 \%$; in the Capilla del Monte pluton, A values $\left(\mu \mathrm{W} / \mathrm{m}^{3}\right)$ above the threshold are between 73 and $77 \% \mathrm{SiO}_{2}$ content; in the Serrezuela pluton, A values above $4.00 \mu \mathrm{W} / \mathrm{m}^{3}$ are found for $\mathrm{SiO}_{2}$ contents between 74 and $78 \%$, with lower A values for concentrations of $\mathrm{SiO}_{2}$ between 72 and 76\%, and with a tendency towards higher A values $\left(\mu \mathrm{W} / \mathrm{m}^{3}\right)$ with the highest $\mathrm{SiO}_{2}$ content (\%). Thus, there are no general patterns or trends of $\mathrm{A}\left(\mu \mathrm{W} / \mathrm{m}^{3}\right)$ for all the intrusions in relation to $\mathrm{SiO}_{2}$ content. For heat-producing elements, when the concentration of Th and U increases (Fig. 5c, d), the heat production increases with a good correlation. For $\mathrm{K}$ the trend is also an increase (Fig. 5b), but with a large spread of data, particularly for concentrations of $K$ between 3 and $6 \%$. From the lithological types, it is not possible to identify a trend between the dominant lithologies (granites, granodiorites, tonalites) and heat production; only trondhjemites are constrained to low values of all elements vs. heat production; granites, despite their wide range of $\mathrm{A}\left(\mu \mathrm{W} / \mathrm{m}^{3}\right)$, are also the only ones that record the highest values. 
A group of samples with particularly high heat production values is shown in Fig. 6 . All the samples are Bt-Ap-rich bodies, hosted in the Achala batholith, particularly in the Achala series defined by Demange et al. (1996), who carried out the differentiation series of the batholith taking into account the aero-radiometric, petrological, mineralogical and geochemical features. These bodies have been recognized by a number of authors, including Lira (1985, 1987), Lira and Kirschbaum (1990), Dorais et al. (1997), and Lira and Sfragulla (2014). Dorais et al. (1997) discuss their formation, indicating the identical age of the enclave granites and the host granite, together with textural, mineralogical and whole-rock geochemical features of the enclaves, among other reasons. The authors suggest that the enclaves are magmatic segregations, i.e., cumulates, and that the F-rich nature of the parent magma would have lowered the viscosity of the melt enough for these accumulations to be formed. These $\mathrm{Bt}$-Ap bodies contain low $\mathrm{SiO}_{2}$ values, between 25 and $50 \%$, and no trend in heat production is observed in relation to their $\mathrm{SiO}_{2}$ content. Their distribution in the field and their existence in depth must be studied, as well as the implementation of a more exhaustive survey of the facies that host them, in order to analyze whether the existence of these anomalies could have any influence on the local thermal regime.

Figure 7a shows a ternary diagram of relative heat production for each heat-producing element, and Fig. 7b shows a ternary diagram of relative concentrations of the same elements. There is a lower variability of $\mathrm{K}$ for all rock types, and its participation in heat production is generally small. The relative $\mathrm{K}$ content in I-type granites is higher than for the other petrogenetic types, although it presents a very wide range (between 0.2 and 0.6). The $\mathrm{K}$ ratio for the other types of rock is below 0.3, except for a few samples of A-type granitoids that exceed this value, with the highest $K$ ratio having a value of 0.78 . In contrast, the proportion of $U$ content is quite variable, with the largest number of samples between 0.0 and 0.6 , in line with the observations made by Veikkolainen et al. (2019). The proportion of Th content is generally dominant, with values between 0.4 and 0.95 . The contours in Fig. $7 \mathrm{~b}$ denote the heat production associated with the relative

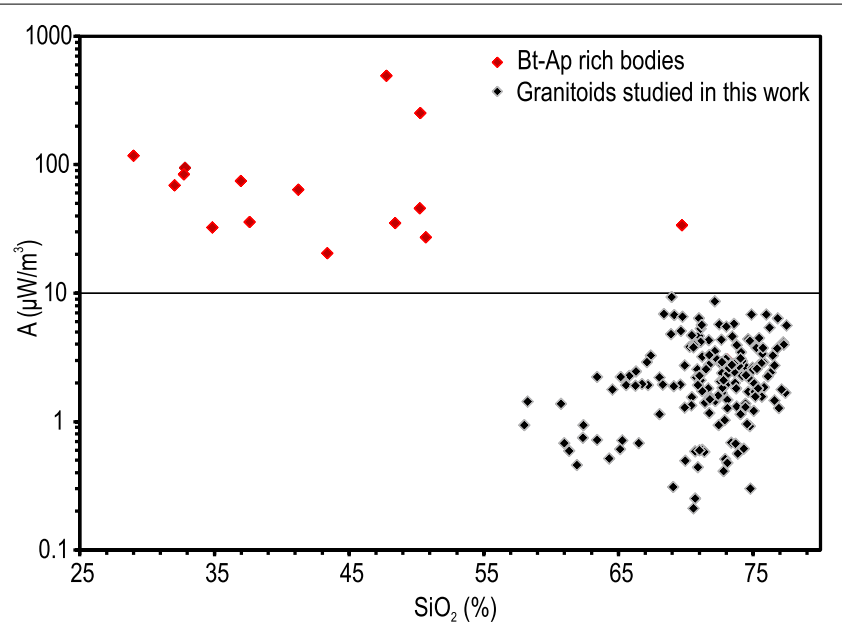

Fig. 6 Bt-Ap-rich bodies ( $N=15)$ of the Achala batholith, showing extremely high heat production values in comparison to the group of granitoid samples analyzed in this work 


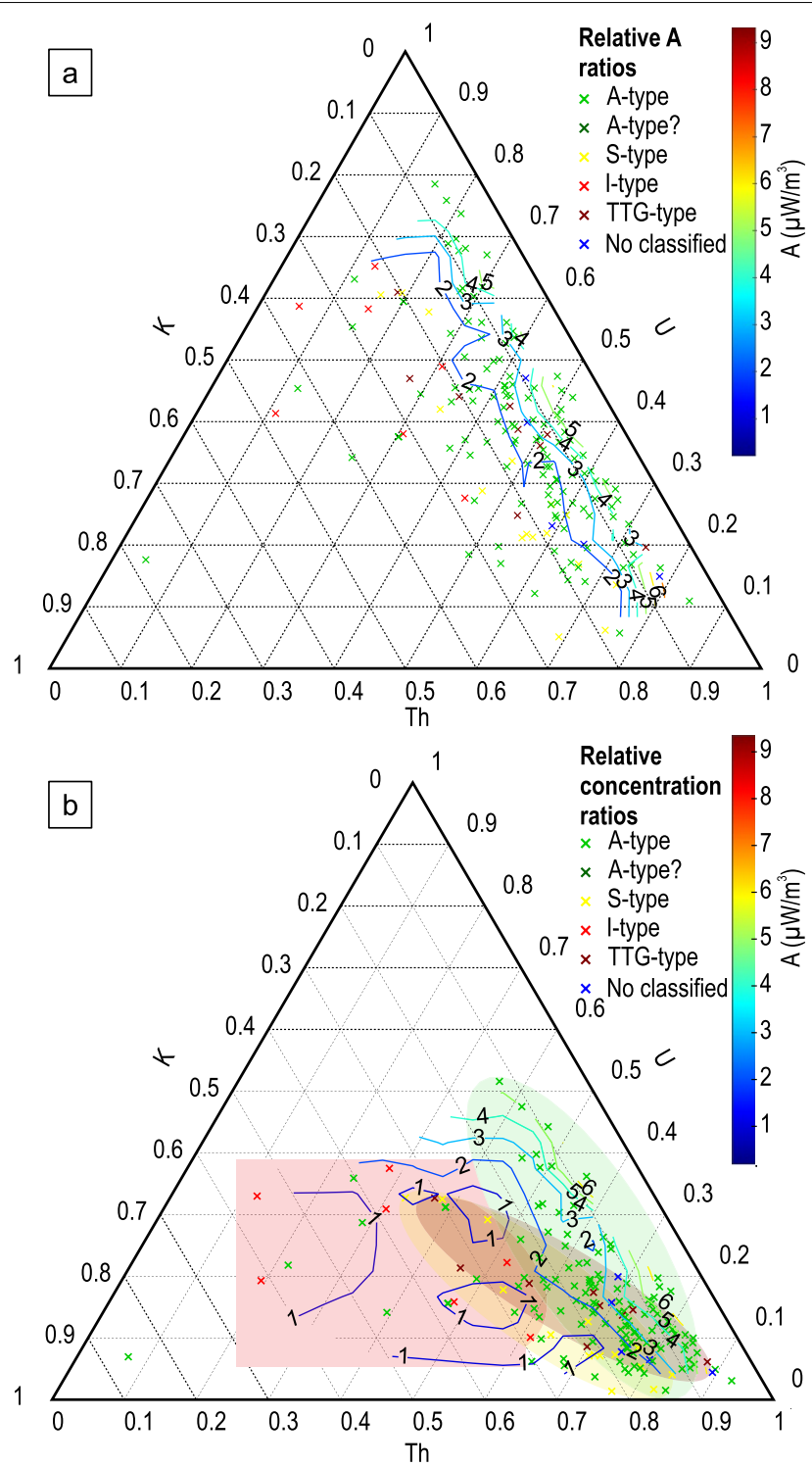

Fig. 7. a Ternary diagram of relative radiogenic heat production by $U$, Th and $K(N=166)$ classified according to petrogenetic types (S-I-A-M classification). The contours correspond to the radiogenic heat production (A). b Ternary diagram of the relative concentrations of the elements $U$, Th and $K(N=166)$ classified according to petrogenetic types (S-I-A-M classification). The contours correspond to the radiogenic heat production (A).The ellipses represent dominant fields for each petrogenetic type (A-type, S-type and I-type, with differentiation for the TTG-type)

concentrations of the elements for the plotted samples, and the ellipses provide representative fields for the rock types analyzed for the Sierras de Córdoba.

\section{Heat reservoirs and thermal manifestations}

The reservoir volume and the magnitude of radioactive heat production per year for the main intrusions are presented in Table 5. The heat reservoir of the Sierra Norte batholith has not been determined because it has an area of $8000 \mathrm{~km}^{2}$ made up of 
Table 5 Estimated heat reserves (J/y) for each granitoid

\begin{tabular}{|c|c|c|c|c|c|c|c|c|}
\hline Granitoid & $\begin{array}{l}\text { Magmatic } \\
\text { event }\end{array}$ & $\begin{array}{l}\text { Erosion } \\
\text { level }^{+}\end{array}$ & $\begin{array}{l}\text { Area } \\
\left(\mathrm{km}^{2}\right)\end{array}$ & $\begin{array}{l}\text { Measured } \\
\text { thickness } \\
(\mathrm{km})\end{array}$ & $\begin{array}{l}\text { Estimated } \\
\text { thickness* } \\
(\mathrm{km})\end{array}$ & $\begin{array}{l}\text { Reservoir } \\
\text { volume } \\
\left(\mathrm{km}^{3}\right)\end{array}$ & $\begin{array}{l}\text { Mean } \\
\text { QA } \\
(\mu \mathrm{J} / \mathrm{g} / \mathrm{y})\end{array}$ & $\begin{array}{l}\text { Heat } \\
\text { reservoir } \\
(\mathrm{J} / \mathrm{y})\end{array}$ \\
\hline$A B$ & Achalian & Top & 2474.00 & $13.00 ?$ & 9.79 & $24,225.08$ & 386.97 & $2.51 E+16$ \\
\hline$A B^{1}$ & Achalian & Top & 2474.00 & $13.00 ?$ & 9.79 & $24,225.08$ & 46.04 & $2.99 \mathrm{E}+15$ \\
\hline$C M P$ & $\begin{array}{l}\text { Carbonifer- } \\
\text { ous }\end{array}$ & Top? & 94.25 & 3.00 & 2.66 & 282.74 & 55.00 & $4.16 \mathrm{E}+13$ \\
\hline$C A B$ & Achalian & Middle & 421.17 & - & 2.42 & 1020.25 & 44.14 & $1.21 \mathrm{E}+14$ \\
\hline$C A B^{2}$ & Achalian & Middle & 44.18 & - & 1.00 & 44.40 & 31.19 & $3.71 E+12$ \\
\hline$C A B^{3}$ & Achalian & Middle & 339.53 & - & 2.13 & 722.73 & 63.56 & $1.23 \mathrm{E}+14$ \\
\hline IGG & Achalian & Top & 196.35 & - & 3.62 & 710.88 & 28.41 & $5.41 E+13$ \\
\hline LOPP & Achalian & Top? & 2.95 & - & 1.04 & 3.06 & 40.94 & $3.36 \mathrm{E}+11$ \\
\hline$S P$ & $\begin{array}{l}\text { Carbonifer- } \\
\text { ous }\end{array}$ & Top & 23.25 & - & 1.99 & 46.35 & 44.11 & $5.72 \mathrm{E}+12$ \\
\hline$\angle P P$ & Famatinian & Middle? & 21.99 & - & 1.04 & 22.97 & 14.38 & $8.84 \mathrm{E}+11$ \\
\hline$G P$ & Famatinian & Middle? & 39.27 & - & 1.19 & 46.90 & 8.04 & $1.01 E+12$ \\
\hline$\angle F P$ & Famatinian & Middle? & 18.85 & - & 0.88 & 16.57 & 5.15 & $2.28 \mathrm{E}+11$ \\
\hline SAP & Famatinian & Middle & 1.96 & - & 0.52 & 1.02 & 3.10 & $8.47 E+09$ \\
\hline Calmayo & Famatinian & Middle & 8.58 & 0.80 & 0.71 & - & - & - \\
\hline El Hongo & Famatinian & Middle & 10.8 & 0.8 & 0.69 & - & - & - \\
\hline La Yeya Sur & Achalian & Middle & 4.12 & $0.5-1.0$ & 0.64 & - & - & - \\
\hline
\end{tabular}

+ The intrusions whose erosion level has been assigned with a question mark do not have information regarding their degree of erosion. In these cases, the erosion level is assigned according to their similarities with other nearby intrusions of the same magmatic event

*Corrected for erosion. For details see Additional file 1: Table S2

${ }^{1}$ Without Bt-Ap-rich bodies samples

${ }^{2}$ Alpa Corral pluton

${ }^{3}$ El Talita pluton

outcrops of multiple intrusions, that emerge at different topographic levels due to the influence of Andean tectonics, making it difficult to determine the level of erosion. The Calmayo, El Hongo and La Yeya Sur intrusions were included in the table as a reference because they have geophysical data, emplacement models and known erosion levels, and were used as analogues for some intrusions with similar characteristics (e.g., same magmatic event, vicinity, geometry).

According to Rollin (1984) and McCay and Younger (2017), even if the heat production in the body is relatively small, large volumes of rock can generate an important heat reservoir. This is the case of the Achala and Cerro Áspero batholiths, which have the biggest heat reservoirs even when they do not have the highest heat production values.

McLaren and Powell (2014) postulate that large batholiths generally involve crustal melting processes, leading to an enrichment in lithophile elements (LILE), including heat-producing elements; thus, they will generally have high radiogenic heat production values. This statement fits properly for the intrusions of the Sierras de Córdoba, where there is a tendency to have a higher heat production per unit volume as the intrusive size increases. The Loma de la Población pluton is excluded from this trend, which with an estimated volume of $3 \mathrm{~km}^{3}$, presents heat production values similar to the Achala batholith. The distribution of the hydrothermal manifestations (Pesce and 


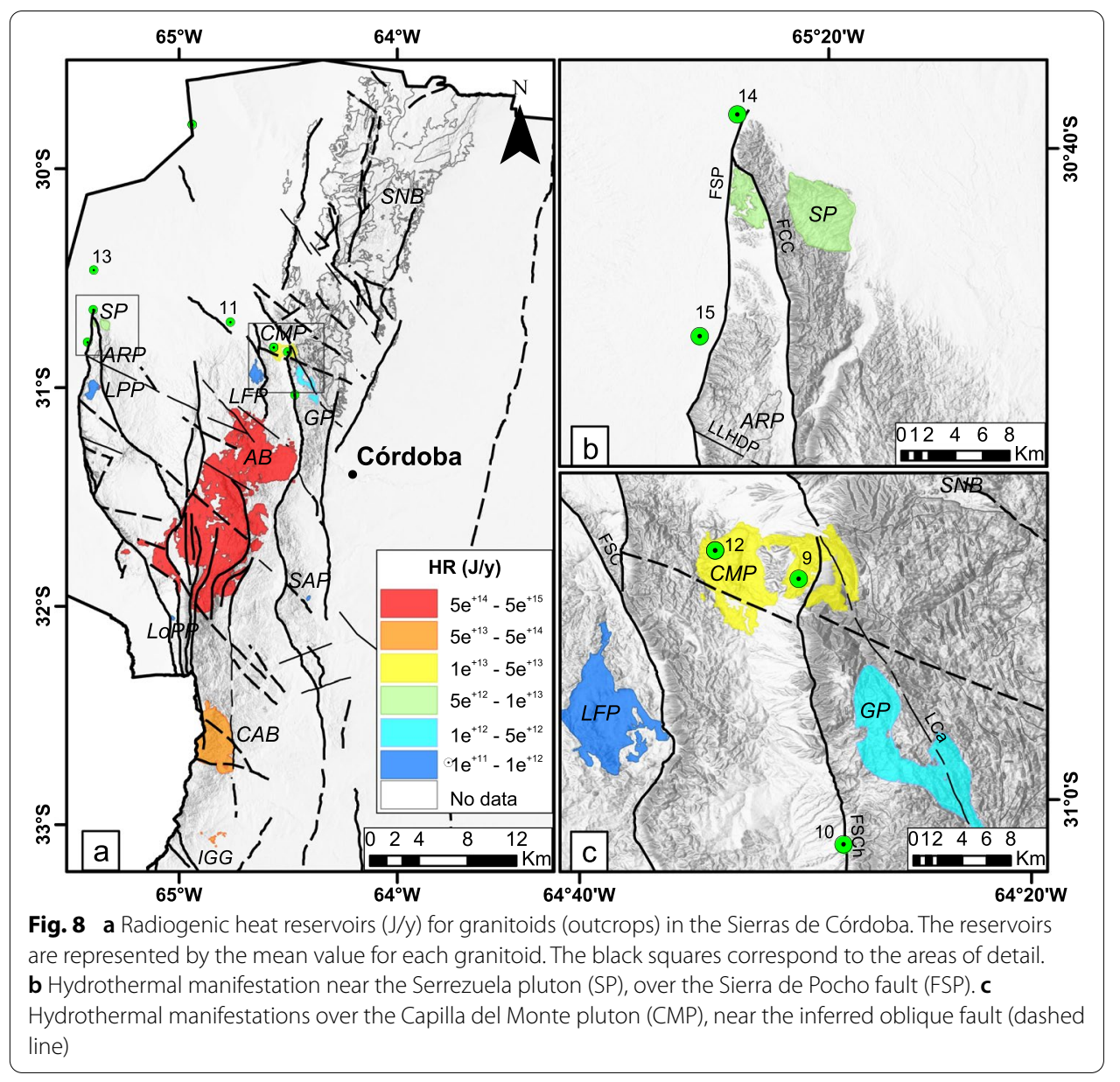

Miranda 2000; Chiodi et al. 2014) and the heat reservoirs is shown in Fig. 8 (green spots). We consider that only those located on the Capilla del Monte pluton could be linked to radiogenic heat production. One of these, called Cerro Uritorco borehole (Fig. 8c, spot $\mathrm{N}^{\circ} 9$ ), has $\sim 550 \mathrm{~m}$ of depth with water at $38^{\circ} \mathrm{C}$ temperature (Pesce 2005; Chiodi 2009; Chiodi et al. 2011, 2014). The other one, called spring of the San Marcos River (Fig. 8c, spot $\mathrm{N}^{\circ} 12$ ), was first described by Sussini et al. (1938) and then referred by Pesce and Miranda (2000) as a zone in which the water has a relatively constant temperature throughout the year, between $21{ }^{\circ} \mathrm{C}$ and $23{ }^{\circ} \mathrm{C}$, but no further information is known. The proximity of these expressions to the oblique lineaments from the Andean neotectonics suggests that they would not only be related to the heat production of the intrusion, but to a conjunction of both factors. The well $\mathrm{N}^{\circ} 1$ in Cruz del Eje (Fig. $8 \mathrm{a}$, spot $\mathrm{N}^{\circ} 11$ ), has $\sim 229 \mathrm{~m}$ of depth with water at $29^{\circ} \mathrm{C}$ temperature (Sussini et al. 1938; Cornaglia et al. 1994); this one seems to be related to the Andean oblique lineaments. The surface distribution of the rest of the hydrothermal manifestations in Sierras de Córdoba is mainly related to larger structures such as the Sierra de Pocho fault (FSP) (Fig. 8a, b, spots $\mathrm{N}^{\circ} 13, \mathrm{~N}^{\circ} 14$ and $\mathrm{N}^{\circ} 15$, named El Quicho, Serrezuela and Piedrita Blanca, respectively) and the Sierra Chica fault (FSCh) (Fig. 8c, spot $\mathrm{N}^{\circ} 10$, named Villa Giardino borehole). El Quicho spring well (Cornaglia et al. 1994; Chiodi 
2009; Chiodi et al. 2011) has $\sim 212 \mathrm{~m}$ of depth and it has a temperature of $39.2{ }^{\circ} \mathrm{C}$. Cornaglia et al. (1994) and Pesce and Miranda (2000) refer to the Serrezuela and Piedrita Blanca manifestations, but there are no available published reports that provide further information. The Villa Giardino borehole has $\sim 600 \mathrm{~m}$ of depth with water at $35^{\circ} \mathrm{C}$ temperature (Chiodi 2009; Chiodi et al. 2011).

\section{Conclusions}

The Sierras de Córdoba are formed of dissimilar granitic intrusions emplaced by a series of magmatic events that occurred during the Paleozoic. The geochemical concentrations of the radiogenic elements of the main granitic intrusions were compiled in a single database to evaluate and analyze the radiogenic heat production, making this the first study of radiogenic heat generation in the area.

The average concentrations of the heat-producing elements for the granitic rocks of the Sierras de Córdoba are $3.78 \pm 2.33 \mathrm{ppm}, 16.60 \pm 10.49 \mathrm{ppm}$ and $2.97 \pm 0.42 \%$ for U, $\mathrm{Th}$ and $\mathrm{K}$, respectively. The mean value of the $\mathrm{Th} / \mathrm{U}$ ratio is $7.27 \pm 6.09$, and the $\mathrm{K} / \mathrm{U}$ ratio is $1.64 \times 104 \pm 1.26 \times 104$. The mean contribution of Th is dominant $(46.24 \%)$, followed by $\mathrm{U}(39.55 \%)$, with a lower participation for K (14.21\%).

The radiogenic heat production showed variability for the different events, which seems to be unrelated to the geological age of the rocks since the half-life of the radiogenic elements is much longer than the age of the intrusions. The decrease in heat generation up to present time for all magmatic events is between 3.2 and $4.3 \%$. The observed variability could be related to the origin and tectonic setting of granite rocks. Our results indicate that A-type granitoids from the Achalian and Carboniferous events have the highest radiogenic heat production. The lowest values correspond to TTG-type granitoids, assigned to the Famatinian event. Low-to-medium values are associated with S-type and I-type magmatism assigned to Famatinian and Pampean events, respectively. This can be the result of the differentiation of the crust over time, dragging higher relative concentrations of incompatible elements towards the most external part of the Earth and as the result of the contamination with crust material of the magmas that gave rise to the A-type intrusions, from re-melting and specializations during their formation.

The Capilla del Monte pluton, Achala batholith, Cerro Áspero batholith, Serrezuela pluton and Loma de la Población pluton are considered MHP granites. These plutons could be viable geothermal resources if a heat-demanding development were proposed within close proximity to these granites and as a supply for any future large heat demand. The Capilla del Monte pluton $\left(4.54 \mu \mathrm{W} / \mathrm{m}^{3}\right)$ should be considered a potential resource as a marginally HHP because it is just slightly below the threshold to be considered an HHP. The Inti Huasi granite, Sierra Norte batholith, La Playa pluton, Güiraldes pluton, La Fronda pluton and San Agustín pluton are LHP granitoids. It is unlikely that these intrusions provide geothermal gradients of interest for direct economic use of the heat.

The Achala and Cerro Áspero batholiths have the biggest heat reservoirs since large volumes of rock can storage large heat reserves. There seems to be direct relationship between the volume of the reservoir and the mean radiogenic heat production per volume, however, the Loma de la Población pluton, with an estimated volume of $3 \mathrm{~km}^{3}$, has heat production values similar to the Achala batholith, with $24,225 \mathrm{~km}^{3}$. 
The proximity of the thermal manifestations located on the Capilla del Monte pluton to the oblique lineaments from the Andean neotectonics suggests that they would not only be related to the heat production of the intrusion, but to a conjunction of both factors. It will be necessary to analyze whether there are any differences in the heat production of the facies of the Capilla del Monte pluton, and if the mega-landslide is influencing the heat storage released by the granitic intrusion. For this purpose, the determination of thermophysical properties should be carried out in order to propose models of temperature variation with depth.

Further studies should also determine the surface heat flow $\left(\mathrm{mW} / \mathrm{m}^{2}\right)$ in order to analyze whether there is any correlation between surface heat flow and radiogenic heat production $\left(\mu \mathrm{W} / \mathrm{m}^{3}\right)$.

\section{Supplementary Information}

The online version contains supplementary material available at https://doi.org/10.1186/s40517-021-00198-9.

Additional file 1. Additional tables. Table $\mathrm{S} 1$ shows the concentrations of $\mathrm{U}$, Th and $\mathrm{K}_{2} \mathrm{O}$, the determination of the Radiogenic Heat Production and other additional data such us $\mathrm{SiO}_{2}$ content, geolocation of the sample, pluton or batholith name, lithological type and crystallization ages of the granitic bodies of the Sierras de Córdoba. Table S2 shows the data used to determine the reservoir volumes for the granitoids and the estimation of the heat reservoirs.

\section{Acknowledgements}

The authors would like to thank Franco M. Francisca for reviewing the manuscript and helping to improve the article, Jorge Rabassa for revising the language and Gustavo Ramé for providing us unpublished data related to the depth of some granitoids. The authors would also like to thank the Reviewers for their comments and suggestions that allowed us to improve this manuscript.

\section{Authors' contributions}

MAC and MP devised the project, the main conceptual ideas and the proof outline. MP compiled and analyzed the database. MP and MECP contributed to the design and implementation of the research, the analysis of the results and the writing of the manuscript. EGA proposed and implemented the methodology for the estimate of reserves, provided support for the analysis of the results and for technical details of the figures. All authors read and approved the final manuscript.

\section{Funding}

This study was funded by the Secretaría de Ciencia y Tecnología (SeCyT) through the Consolidar project called "Integración de datos geoespaciales para la zonificación y caracterización geológico-geotécnica de rocas graníticas y granitoides de las Sierras de Córdoba" (SeCyT resolution 455/18). MP studies are funded with a doctoral scholarship granted by the Secretaría de Ciencia y Tecnología (SeCyT). EGA studies are funded with a doctoral scholarship granted by the Consejo Nacional de Investigaciones Científicas y Técnicas (CONICET).

\section{Availability of data and materials}

All data generated or analyzed during this study are included in this published article (and its Additional file 1).

\section{Declarations}

\section{Competing interests}

The authors declare that they have no competing interests.

\section{Author details}

${ }^{1}$ Facultad de Ciencias Exactas, Físicas y Naturales, Universidad Nacional de Córdoba, Av. Vélez Sarsfield 1611 X5016CGA Córdoba, Argentina. ${ }^{2}$ Secretaría de Ciencia y Tecnología (SeCyT), Universidad Nacional de Córdoba, Dr. Juan Filloy, X5016CGA Córdoba, Argentina. ${ }^{3}$ Instituto de Estudios Avanzados en Ingeniería y Tecnología (IDIT), Universidad Nacional de Córdoba, Av. Vélez Sarsfield 1611, X5016CGA Córdoba, Argentina. ${ }^{4}$ Consejo Nacional de Investigaciones Científicas y Técnicas (CONICET), Av. Vélez Sarsfield 1611, X5016CGA Córdoba, Argentina.

Received: 17 February 2021 Accepted: 29 May 2021

Published online: 10 June 2021 


\section{References}

Abbady AGE, Al-Ghamdi AH. Heat production rate from radioactive elements of granite rocks in north and southeastern Arabian shield Kingdom of Saudi Arabia. J Radiat Res and Appl Sci. 2018;11(4):281-90. https://doi.org/10.1016/j.jras. 2018.03.002.

Artemieva IM. The Lithosphere: An Interdisciplinary Approach. 1st ed. Cambridge: Cambridge University Press; 2011.

Artemieva IM, Mooney WD. Thermal thickness and evolution of Precambrian lithosphere: a global study. J Geophys Res. 2001;106(B8):16387-414. https://doi.org/10.1029/2000JB900439.

Artemieva IM, Thybo H, Jakobsen K, Sørensen NK, Nielsen LS. Heat production in granitic rocks: Global analysis based on a new data compilation GRANITE2017. Earth-Sci Rev. 2017;172:1-26. https://doi.org/10.1016/j.earscirev.2017.07.003.

Artola MF, del Hoyo S, Enrique C, Alves M. Balance Energético Nacional: Serie histórica - Indicadores desde 1960 actualizado al año 2018. Argentina: Subsecretaría de Planeamiento Energético. Nov 2019. Available from: http:// www.energia.gob.ar/contenidos/archivos/Reorganizacion/informacion_del_mercado/publicaciones/energia_ en_gral/balances_provinciales/2019_11_10_sintesis_balances_energeticos_2018_pub.pdf. Accessed 28 Mar 2021.

Ashwal LD, Morgan P, Kelley SA, Percival JA. Heat production in an Archean crustal profile and implications for heat flow and mobilization of heat-producing elements. Earth Planet Sci Lett. 1987;85(4):439-50.

Carignano CA, Cioccale MA, Martino RD. El megadeslizamiento del Cerro Uritorco, ladera occidental de la Sierra Chica de Córdoba. Revista De La Asoc Geol Argent. 2014;71(1):21-32.

Chappell BW, White AJR. Two contrasting granite types. Pac Geol. 1974;8(2):173-4.

Chappell BW, White AJR. Two contrasting granite types: 25 years later. Aust J Earth Sci. 2001;48(4):489-99. https://doi. org/10.1046/j.1440-0952.2001.00882.x.

Chiodi AL. Tectónica extensional cretácica y manifestaciones hidrotermales en la provincia de Córdoba [Bachelor's degree thesis]. Córdoba: Universidad Nacional de Córdoba; 2009.

Chiodi A, Martino R, Fernández G, Formica S. Manifestaciones hidrotermales en la provincia de Córdoba: caracterización geoquímica e isotópica y su relación con la tectónica. In: García RF, Rocha Fasola MV, editors. $7^{\circ}$ Congreso Argentino de Hidrogeología y V Seminario Hispano-Latinoamericano Sobre Temas Actuales de la Hidrología Subterránea. Salta: Asociación Civil Grupo Argentino de la Asociación Internacional de Hidrogeólogos; 2011. p. 3-10.

Chiodi AL, Martino RD, Báez WA, Fórmica S, Fernández G. Recursos geotérmicos. In: Martino RD, Guereschi AB, editors, Geología y Recursos Naturales de la provincia de Córdoba. Córdoba: Asociación Geológica Argentina; 2014. p. 349-63.

Clemens JD. S-type granitic magmas-petrogenetic issues, models and evidence. Earth-Sci Rev. 2003;61(1-2):1-18.

Coniglio JE. Evolución petrológica y metalogenética del batolito Cerro Áspero en relación con el ciclo geoquímico endógeno del flúor, Sierra de Comechingones, Córdoba, Argentina [PhD thesis]. Río Cuarto: Universidad Nacional de Río Cuarto; 2006

Cornaglia J, Moreno R, Millone H, Lis E. Aguas termales en la Provincia de Córdoba. Córdoba: Secretaría de Minería de la Provincia de Córdoba; 1994. p. 8.

Cruden AR, McCaffrey KJW. Growth of plutons by floor subsidence: implications for rates of emplacement, intrusion spacing and melt-extraction mechanisms. Phys Chem Earth Pt a. 2001;26(4-5):303-15.

D'Eramo FJ, Pinotti LP, Bonalumi A, Sfragulla J, Demartis M, Coniglio J, et al. El magmatismo ordovícico de las Sierras Pampeanas de Córdoba. In: Martino RD, Guereschi AB, editors. Geología y Recursos Naturales de la provincia de Córdoba. Córdoba: Asociación Geológica Argentina; 2014. p. 233-54.

Dahlquist JA, Pankhurst RJ, Gaschnig RM, Rapela CW, Casquet C, Alasino PH, Galindo C, Baldo EG. Hf and Nd isotopes in Early Ordovician to Early Carboniferous granites as monitors of crustal growth in the Proto-Andean margin of Gondwana. Gondwana Res. 2013;23(4):1671-1630.

Dahlquist JA, Pankhurst RJ, Rapela CW, Basei MA, Alasino PH, Saavedra J, Baldo EG, Murra JA, Neto MD. The Capilla del Monte pluton, Sierras de Córdoba, Argentina: the easternmost Early Carboniferous magmatism in the pre-Andean SW Gondwana margin. Int J Earth Sci. 2016;105(5):1287-305. https://doi.org/10.1007/ s00531-015-1249-0.

Demange M, Álvarez JO, López L, Zarco JJ. The Achala Batholith (Córdoba, Argentina): a composite intrusion made of five independent magmatic suites. Magmatic evolution and deuteric alteration. J S Am Earth Sci. 1996;9(1-2):11-25.

Dorais MJ, Lira R, Chen Y, Tingey D. Origin of biotite-apatite-rich enclaves, Achala batholith, Argentina. Contrib Miner Petrol. 1997;130(1):31-46.

Eby GN. Chemical subdivision of the A-type granitoids: petrogenetic and tectonic implications. Geology. 1992;20(7):6414. https://doi.org/10.1130/0091-7613(1992)020\%3c0641:CSOTAT\%3e2.3.CO;2.

Frost BR, Barnes CG, Collins WJ, Arculus RJ, Ellis DJ, Frost CD. A geochemical classification for granitic rocks. J Petrol. 2001;42(11):2033-48. https://doi.org/10.1093/petrology/42.11.2033.

Gillespie MR, Crane EJ, Barron HF. Deep geothermal energy potential in Scotland. Keyworth, Nottingham: British Geological Survey Commissioned Report; 13 Nov 2013. CR 12/131. Available from: https://www.gov.scot/publications/ study-potential-deep-geothermal-energy-scotland-volume-2/. Accessed 28 Mar 2021.

Hasterok D, Chapman DS. Heat production and geotherms for the continental lithosphere. Earth Planet Sc Lett. 2011;307(1-2):59-70. https://doi.org/10.1016/j.epsl.2011.04.034.

Hasterok D, Gard M, Webb J. On the radiogenic heat production of metamorphic, igneous, and sedimentary rocks. Geosci Front. 2018;9(6):1777-94. https://doi.org/10.1016/j.gsf.2017.10.012.

Jackson N, Willis-Richards J, Manning D, Sams M. Evolution of the Cornubian ore-field, southwest England: Part II Mineral deposits and ore-forming processes. Econ Geol. 1989;84:1101-33.

Jaupart C, Mareschal JC. Heat flow and thermal structure of the lithosphere. In: Watts AB, Schubert G, editors. Treatise on geophysics. Amsterdam: Elsevier; 2007. p. 217-52.

Jaupart C, Mareschal JC. Post-orogenic thermal evolution of newborn Archean continents. Earth Planet Sc Lett. 2015;432:36-45. https://doi.org/10.1016/j.epsl.2015.09.047. 
Jaupart C, Mareschal J, larotsky L. Radiogenic heat production in the continental crust. Lithos. 2016;262(1):398-427. https://doi.org/10.1016/j.lithos.2016.07.017.

Kemp TIS. The petrogenesis of granitic rocks: a source-based perspective [PhD thesis]. Canberra: The Australian National University; 2001.

Kemp AIS, Hawkesworth CJ. Granitic perspectives on the generation and secular evolution of the continental crust. In: Rudnick RL, editor. The Crust, Treatise on Geochemistry, vol. 3. Oxford: Elsevier-Pergamon; 2003. p. 349-410.

Leal PR, Hartmann LA, Santos JO, Miró RC, Ramos VA. Volcanismo postorogénico en el extremo norte de las Sierras Pampeanas Orientales: Nuevos datos geocronológicos y sus implicancias tectónicas. Revista De La Asoc Geol Argent. 2003:58(4):593-607.

Leat PT, Jordan TA, Flowerdew MJ, Riley TR, Ferraccioli F, Whitehouse MJ. Jurassic high heat production granites associated with the Weddell Sea rift system. Antarctica Tectonophysics. 2018;722:249-64. https://doi.org/10.1016/j.tecto. 2017.11.011.

Lira R. Tipología y evolución de rocas graníticas en su relación con el hemiciclo endógeno de la geoquímica del uranio. Aspectos metalogénicos. Sector septentrional del batolito de Achala. Provincia de Córdoba [PhD thesis]. Córdoba: Universidad Nacional de Córdoba; 1985.

Lira R. Episienitas feldespáticas y su relación con depósitos uraníferos en el batolito de Achala, provincia de Córdoba. Revista De La Asoc Geol Argent. 1987;42(3-4):388-406.

Lira R, Kirschbaum AM. Geochemical evolution of granites from the Achala batholith of the Sierras Pampeanas, Argentina. In: Kay SM, Rapela CW, editors. Plutonism from Antarctica to Alaska. Special Paper 241. Colorado: Geological Society of America; 1990. p. 67-76.

Lira R, Sfragulla J. El magmatismo devónico-carbonífero: el batolito de Achala y plutones menores al norte del cerro Champaquí. In: Martino RD, Guereschi AB, editors. Geología y Recursos Naturales de la provincia de Córdoba. Córdoba: Asociación Geológica Argentina; 2014. p. 293-347.

Lira R, Millone HA, Kirschbaum AM, Moreno RS. Calc-alkaline arc granitoid activity in the Sierra Norte-Ambargasta Ranges, central Argentina. J S Am Earth Sci. 1997;10(2):157-77.

Lira R, Poklepovic MF, O'leary MS. El magmatismo cámbrico en el batolito de Sierra Norte-Ambargasta. In: Martino RD, Guereschi AB, editors. Geología y Recursos Naturales de la provincia de Córdoba. Córdoba: Asociación Geológica Argentina; 2014. p. 183-216.

Loiselle MC, Wones DR. Characteristics and origin of anorogenic granites. Geol Soc Am Abst Prog. 1979;1 1(7):468.

Mareschal JC, Jaupart C. Radiogenic heat production, thermal regime and evolution of continental crust. Tectonophysics. 2013;609(8):524-34. https://doi.org/10.1016/j.tecto.2012.12.001.

Massabie A. Neotectónica y sismicidad en la región de las Sierras Pampeanas Orientales, Sierra de Córdoba, Argentina. In: Asociación Geológica Argentina, editor. 10 Congreso Geológico Argentino. San Miguel de Tucumán: Asociación Geológica Argentina; 1987. p. 271-74.

Massabie A, Sanguinetti A, Lo Forte G, Cegarra M. La actividad neotectónica en la sierra Baja de San Marcos-Cruz del Eje, flanco occidental de las Sierras Pampeanas Orientales. Revista De La Asoc Geol Argent. 2003;58(4):653-63.

McCaffrey KJW, Petford N. Are granitic intrusions scale invariant? J Geol Soc London. 1997;154(1):1-4. https://doi.org/10. 1144/gsjgs.154.1.0001.

McCay AT, Younger PL. Ranking the geothermal potential of radiothermal granites in Scotland: are any others as hot as the Cairngorms? Scot J Geol. 2017;53(1):1-11. https://doi.org/10.1144/sjg2016-008.

McLaren S, Powell R. Magmatism, orogeny and the origin of high-heat-producing granites in Australian Proterozoic terranes. J Geol Soc London. 2014;171(2):149-52. https://doi.org/10.1144/jgs2013-040.

McLaren S, Sandiford M, Powell R, Neumann N, Woodhead J. Palaeozoic intraplate crustal anatexis in the Mount Painter Province, South Australia: timing, thermal budgets and the role of crustal heat production. J Petrol. 2006;47(12):2281-302. https://doi.org/10.1093/petrology/egl044.

McLennan SM, Nance WB, Taylor SR. Rare earth element-thorium correlations in sedimentary rocks, and the composition of the continental crust. Geochim Cosmochim Ac. 1980;44(11):1833-9.

Miró RC, Schwartz J, Gromet P. Magmatismo Calcoalcalino en la Sierra Norte de Córdoba. Su Extensión Temporal. Ser Corr Geol. 2004;19:199-211.

O'Leary MS, Lira R, Poklepovic MF. Volcanismo y subvolcanismo del sector centro-oeste del batolito de Sierra NorteAmbargasta. In: Martino RD, Guereschi AB, editors. Geología y Recursos Naturales de la provincia de Córdoba. Córdoba: Asociación Geológica Argentina; 2014. p. 217-32.

Otamendi J, Cristofolini E, Fagiano M, Pinotti L, D'Eramo F. Los Granitos Devónicos del sur de la Sierra de Comechingones. In: Martino RD, Guereschi AB, editors. Geología y Recursos Naturales de la provincia de Córdoba. Córdoba: Asociación Geológica Argentina; 2014. p. 277-91.

Pesce AH. Argentina Country Update. In: Horne R, Okadan E, editors. Proceedings World Geothermal Congress 2005. Antalya: International Geothermal Association; 2005. p. 12.

Pesce AH, Miranda F. Catálogo de Manifestaciones Termales de la República Argentina Volumen II-Región Noreste Centro y Sur. Argentina: Subsecretaría de Minería de la Nación, Instituto de Geología y Recursos Minerales (IGRM), Servicio Geológico Minero Argentino (SEGEMAR); 2000.

Petford N, Cruden AR, McCaffrey KJW, Vigneresse JL. Granite magma formation, transport and emplacement in the Earth's crust. Nature. 2000;408(6813):669-73.

Pinotti L, Coniglio JE, D'Eramo F, Demartis M, Otamendi JE, Fagiano MR, Zambroni NE. El magmatismo devónico: Geología del batolito de Cerro Aspero. In: Martino RD, Guereschi AB, editors. Geología y Recursos Naturales de la provincia de Córdoba. Córdoba: Asociación Geológica Argentina; 2014. p. 255-76.

Rapela CW, Pankhurst RJ, Casquet C, Baldo EG, Saavedra J, Galindo C, Fanning CM. The Pampean Orogeny of the southern proto-Andes: Cambrian continental collision in the Sierras de Córdoba. Geol Soc Spec Publ. 1998;142(1):181-217.

Rollin KE. Gravity modelling of the eastern Highlands granites in relation to heat flow studies. In: Investigation of the Geothermal Potential of the UK. Keyworth: British Geological Survey; 1984. p. 17.

Rybach L. Radioactive heat production: a physical property determined by the chemistry of rocks. In: Strens RGJ, editor. The Physics and Chemistry of Minerals and Rocks. London: Wiley and Sons; 1976. p. 309-18. 
Rybach L. Determination of heat production rate. In: Hänel R, Rybach L, Stegena L, editors. Handbook of terrestrial heat flow density determination. Dordrecht: Springer; 1988. p. 125-42.

Siegel C, Bryan SE, Purdy D, Gust D, Allen C, Uysal T, et al. A new database compilation of whole-rock chemical and geochronological data of igneous rocks in Queensland: a new resource for HDR geothermal resource exploration. In: Budd AR, editor., et al., Proceedings of the 2011 Australian Geothermal Energy Conference. Australia: Geoscience Australia; 2011. p. 239-44.

Sims JP, Ireland TR, Camacho A, Lyons P, Pieters PE, Skirrow RG, Stuart-Smith PG, Miró R. U-Pb, Th-Pb and Ar-Ar geochronology from the southern Sierras Pampeanas Argentina: implications for the Paleozoic tectonic evolution of the western Gondwana margin. In: Pankhurst RJ, Rapela CW, editors. The Proto-Andean Margin of South America, vol. 142. London: Geological Society London Special Publications; 1998. p. 259-81 (10.1144/GSL.SP.1998.142.01.13).

Sussini M, Herrero Ducloux E, Brandán R, Isnardi H, Galmarini A, Castillo M, et al. Aguas Minerales de la República Argentina: Provincia de Córdoba, vol. 4. Buenos Aires: Comisión Nacional de Climatología y Aguas Minerales. 1938. Ley № 11621. Available from: http://repoarchivos.segemar.gob.ar/Mounted/KOHA\%20-\%20DSPACE\%20DISCK2/KOHA\% 20-\%20Biblioteca\%20Digital\%20SEGEMAR/Biblioteca\%20SEGEMAR\%20-\%20Tesoro,\%20Tratados\%20de\%20len guas,\%20Monografias\%20en\%20idiomas\%20extranjeros,\%20y\%20varios\%20para\%20ver\%20clasificaci\%C3\%B3n/ Aguas\%20minerales\%20R.A/2337/2337.pdf. Accessed 28 Mar 2021.

Veikkolainen T, Kukkonen IT, Näslund JO. Radiogenic heat production analysis of Fennoscandian Shield and adjacent areas in Sweden. Geophys J Int. 2019;218(1):640-54.

Wasserburg GJ, MacDonald GJ, Hoyle F, Fowler WA. Relative contributions of uranium, thorium, and potassium to heat production in the Earth. Science. 1964;143(3605):465-7.

Wedepohl KH. The composition of the continental crust. Geochim Cosmochim Ac. 1995;59(7):1217-32.

White AJR. Sources of granite magmas. Geol Soc Amer Abstr Programs. 1979;11:539.

Zhou ZM, Ma CQ, Qi SH, Xi YF, Liu W. Late Mesozoic high-heat-producing (HHP) and high-temperature geothermal reservoir granitoids: The most significant geothermal mechanism in South China. Lithos. 2020;366:367. https://doi. org/10.1016/j.lithos.2020.105568.

\section{Publisher's Note}

Springer Nature remains neutral with regard to jurisdictional claims in published maps and institutional affiliations.

\section{Submit your manuscript to a SpringerOpen ${ }^{\circ}$ journal and benefit from:}

- Convenient online submission

- Rigorous peer review

Open access: articles freely available online

- High visibility within the field

Retaining the copyright to your article

Submit your next manuscript at $\boldsymbol{s p r i n g e r o p e n . c o m ~}$ 